\title{
S. cerevisiae Trm140 has two recognition modes for 3-methylcytidine modification of the anticodon loop of tRNA substrates
}

\author{
LU HAN, ERIN MARCUS, SONIA D'SILVA, and ERIC M. PHIZICKY \\ Department of Biochemistry and Biophysics, Center for RNA Biology, University of Rochester School of Medicine, Rochester, New York 14642, USA
}

\begin{abstract}
The 3-methylcytidine $\left(\mathrm{m}^{3} \mathrm{C}\right)$ modification is ubiquitous in eukaryotic tRNA, widely found at $\mathrm{C}_{32}$ in the anticodon loop of tRNA ${ }^{\text {Thr }}$, tRNA $^{\text {Ser }}$, and some tRNA ${ }^{\text {Arg }}$ species, as well as in the variable loop (V-loop) of certain tRNA ${ }^{\text {Ser }}$ species. In the yeast Saccharomyces cerevisiae, formation of $\mathrm{m}^{3} \mathrm{C}_{32}$ requires Trm140 for six tRNA substrates, including three tRNA ${ }^{\text {Thr }}$ species and three tRNA species, whereas in Schizosaccharomyces pombe, two Trm140 homologs are used, one for tRNA ${ }^{\text {Thr }}$ and one for tRNA ${ }^{\text {Ser }}$. The occurrence of a single Trm140 homolog is conserved broadly among Ascomycota, whereas multiple Trm140-related homologs are found in metazoans and other fungi. We investigate here how $S$. cerevisiae Trm140 protein recognizes its six tRNA substrates. We show that Trm140 has two modes of tRNA substrate recognition. Trm140 recognizes $G_{35}-U_{36}-t^{6} A_{37}$ of the anticodon loop of tRNA $^{\mathrm{Thr}}$ substrates, and this sequence is an identity element because it can be used to direct $\mathrm{m}^{3} \mathrm{C}$ modification of $t R N A^{\text {Phe }}$. However, Trm140 recognition of $t R N A^{\text {Ser }}$ substrates is different, since their anticodons do not share $\mathrm{G}_{35}-\mathrm{U}_{36}$ and do not have any nucleotides in common. Rather, specificity of Trm140 for tRNA ${ }^{\text {Ser }}$ is achieved by seryl-tRNA synthetase and the distinctive tRNA ${ }^{\text {Ser }} V$-loop, as well as by $t^{6} A_{37}$ and $i^{6} A_{37}$. We provide evidence that all of these components are important in vivo and that seryl-tRNA synthetase greatly stimulates $\mathbf{m}^{3} \mathrm{C}$ modification of $\operatorname{tRNA}^{\text {Ser(CGA) }}$ and tRNA ${ }^{\text {Ser(UGA) }}$ in vitro. In addition, our results show that Trm140 binding is a significant driving force for tRNA modification and suggest separate contributions from each recognition element for the modification.
\end{abstract}

Keywords: 3-methylcytidine; methyltransferase; modification; tRNA; specificity; anticodon loop

\section{INTRODUCTION}

tRNA undergoes extensive post-transcriptional modifications in all domains of life to ensure the efficiency and accuracy of translation. In the yeast Saccharomyces cerevisiae, each cytoplasmic tRNA has an average of 12.6 modifications, with $\sim 10$ modifications in the main body of the tRNA and $\sim 2.6$ modifications in the anticodon loop region, comprising residues $\mathrm{N}_{32}-\mathrm{N}_{38}$ of the anticodon loop and the neighboring $\mathrm{N}_{31}-\mathrm{N}_{39}$ base pair of the anticodon stem (Juhling et al. 2009). Modifications within the tRNA body often contribute to folding or stability (Helm et al. 1999; Kadaba et al. 2004; Alexandrov et al. 2006; Whipple et al. 2011). In contrast, modifications in the anticodon (primarily at the wobble nucleotide $\mathrm{N}_{34}$ ) or at $\mathrm{N}_{37}$ often contribute to accurate decoding and reading frame maintenance (Gerber and Keller 1999; Bjork et al. 2001, 2007; Urbonavicius et al. 2001; Murphy and Ramakrishnan 2004; Esberg et al. 2006; Agris et al. 2007;

Corresponding author: eric_phizicky@urmc.rochester.edu 116.

Article is online at http://www.rnajournal.org/cgi/doi/10.1261/rna.059667.
Waas et al. 2007; Weixlbaumer et al. 2007; Johansson et al. 2008; Chen et al. 2011; El Yacoubi et al. 2011).

Modifications occurring at other residues within the anticodon loop region also have important roles in tRNA function. For example, a yeast pus $3 \Delta$ mutant, which lacks pseudouridine at $U_{38}$ or $U_{39}$, is temperature sensitive, primarily due to reduced tRNA ${ }^{\mathrm{Gln}(\mathrm{UUG})}$ function (Han et al. 2015); and a yeast $t r m 7 \Delta$ mutant, which lacks $2^{\prime}-O$ methylation at $\mathrm{C}_{32}(\mathrm{Cm})$ as well as $\mathrm{Gm}_{34}$, grows poorly due to reduced translation and reduced $\mathrm{tRNA}^{\mathrm{Phe}}$ function (Pintard et al. 2002; Guy et al. 2012). $\mathrm{N}_{32}$ and $\mathrm{N}_{38}$ are at the borders of the anticodon loop, often form a noncanonical base pair (Auffinger and Westhof 1999), and have been shown to be critical for ribosome binding and decoding (Lustig et al. 1993; Olejniczak et al. 2005; Olejniczak and Uhlenbeck 2006; Ledoux et al. 2009).

(C) 2017 Han et al. This article is distributed exclusively by the RNA Society for the first 12 months after the full-issue publication date (see http:// rnajournal.cshlp.org/site/misc/terms.xhtml). After 12 months, it is available under a Creative Commons License (Attribution-NonCommercial 4.0 International), as described at http://creativecommons.org/licenses/by-nc/ $4.0 \%$ 
The 3-methylcytidine $\left(\mathrm{m}^{3} \mathrm{C}\right)$ modification is also found at $\mathrm{C}_{32}$ in the anticodon loop of tRNAs and likely has an important role. $\mathrm{m}^{3} \mathrm{C}$ is found at $\mathrm{C}_{32}$ of all four characterized eukaryotic cytoplasmic tRNA ${ }^{\text {Thr }}$ species, 18 of the 20 characterized cytoplasmic tRNA ${ }^{\mathrm{Ser}}$ species, and two of five characterized eukaryotic tRNA ${ }^{\mathrm{Arg}}$ species that have an encoded $\mathrm{C}_{32}$, as well as at residue e2 of the tRNA ${ }^{\text {Ser }}$ variable loop (V-loop) in animals (Weissenbach et al. 1977; Juhling et al. 2009; Machnicka et al. 2013; Arimbasseri et al. 2016). The $\mathrm{m}^{3} \mathrm{C}$ modification is formed by members of the $\operatorname{Trm} 140 \mathrm{~m}^{3} \mathrm{C}$ methyltransferase family. In S. cerevisiae, TRM140 is required for $\mathrm{m}^{3} \mathrm{C}_{32}$ modification of six tRNA species, including all three tRNA ${ }^{\text {Thr }}$ species, with anticodons IGU, CGU, and UGU, and the three tRNA ${ }^{\text {Ser }}$ species with anticodons CGA, UGA, and GCU (D'Silva et al. 2011; Noma et al. 2011), while tRNA ${ }^{\mathrm{Ser}(\mathrm{IGA})}$ does not have $\mathrm{C}_{32}$. In contrast, in Schizosaccharomyces pombe there are two TRM140 homologs; trm $140^{+}$is required for modification of all three $\mathrm{RNA}^{\mathrm{Thr}}$ species, whereas trm $141^{+}$is required for modification of all four $\mathrm{tRNA}^{\mathrm{Ser}}$ species (Arimbasseri et al. 2016). Although S. cerevi-

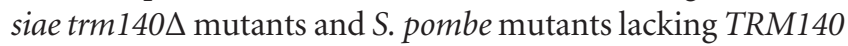
and/or TRM141 have no growth defect in a variety of media (D'Silva et al. 2011; Arimbasseri et al. 2016), the importance of $\mathrm{m}^{3} \mathrm{C}_{32}$ is underscored by the growth defect of $S$. cerevisiae

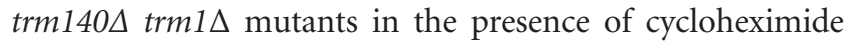

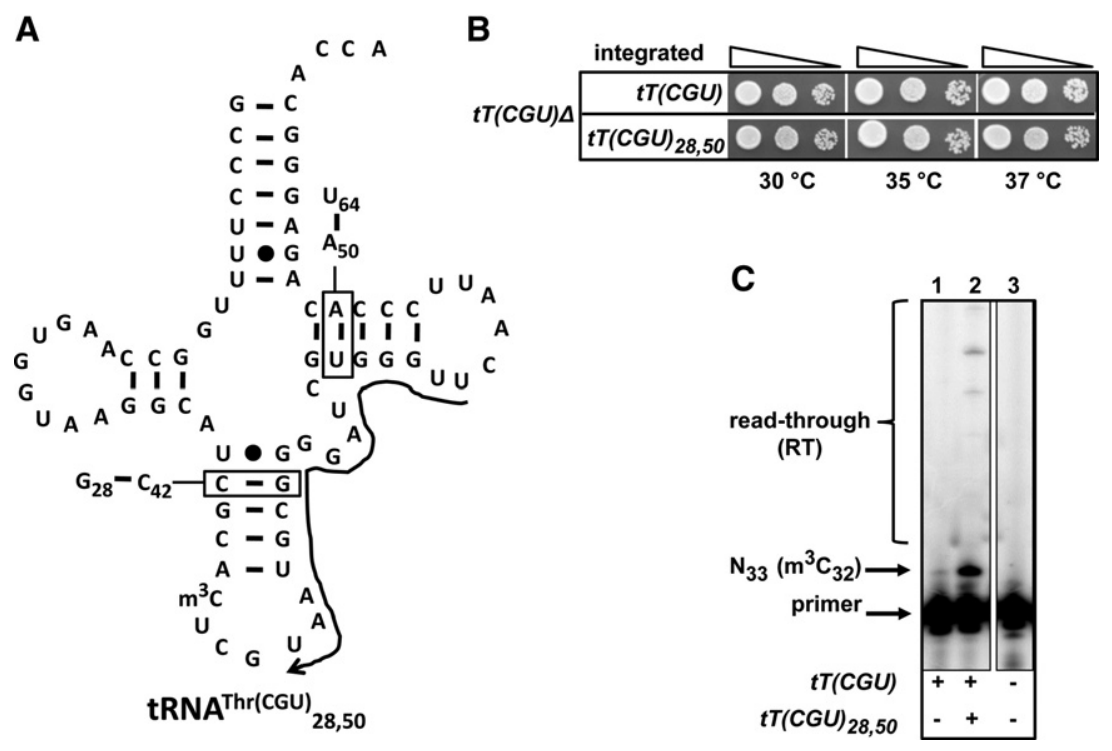

FIGURE 1. The tRNA ${ }^{\text {Thr(CGU) }}{ }_{28,50}$ scaffold used for analysis of tRNA ${ }^{\text {Thr }}$ variants is fully functional and efficiently modified to $\mathrm{m}^{3} \mathrm{C}$. (A) Schematic of tRNA ${ }^{\mathrm{Thr}(\mathrm{CGU})}{ }_{28,50}$. The secondary structure of $\mathrm{tRNA}^{\mathrm{Thr}(\mathrm{CGU})}$ is shown. The base pairs of residues 28:42 and 50:64 are switched as indicated in the boxes. The primer complementary to residues 55-36 is indicated with a $3^{\prime}$ arrow. (B) tRNA ${ }^{\mathrm{Thr}(\mathrm{CGU})}{ }_{28,50}$ is functional in vivo. $t T(C G U) \Delta$ cells containing the integrated WT $t T$ $(C G U)$ or $t T(C G U)_{28,50}$ as indicated were grown overnight in YPD medium, serially diluted and spotted onto YPD medium, and plates were incubated at indicated temperatures for 3 d. (C) tRNA ${ }^{\mathrm{Thr}(\mathrm{CGU})}{ }_{28,50}$ is efficiently modified to $\mathrm{m}^{3} \mathrm{C}_{32}$. Bulk RNA from cells containing the integrated WT $t T(C G U)$ or $t T(C G U)_{28,50}$ as indicated were analyzed by primer extension assay, as described in Materials and Methods, using the primer shown in A. The vast majority of tRNA $^{\mathrm{Thr}(\mathrm{CGU})}{ }_{28,50}$ has $\mathrm{m}^{3} \mathrm{C}_{32}$ based on the primer extension stop at $\mathrm{U}_{33}$, compared to the amount of read-through (RT).
(D'Silva et al. 2011), and by the broad conservation of the TRM140 family and the $\mathrm{m}^{3} \mathrm{C}$ modification in eukaryotes.

One important question about S. cerevisiae $\operatorname{Trm} 140$ is how it recognizes its specific tRNA substrates. For enzymes such as Pus3 that modify the same residues in every tRNA, recognition typically exploits a common structural feature of tRNAs (Hur and Stroud 2007). For enzymes such as the tRNA ${ }^{\mathrm{His}}$ uanylyltransferase Thg1, which only modifies tRNA ${ }^{\text {His }}$, recgnition of the unique GUG anticodon drives modification Jackman and Phizicky 2006; Nakamura et al. 2013). , several modifying enzymes recognize a specific examples Trm10 for 13 of 24 species with $G_{9}$ (Swinehart et al. 2013; Swinehart and Jackman 2015) and the $\mathrm{Cm}_{32}$ and $\mathrm{Gm}_{34}$ modification catalyzed by Trm7 on three tRNA species (Pintard et al. 2002), as well as the $\mathrm{m}^{3} \mathrm{C}_{32}$ modification catalyzed by S. cerevisiae Trm140 on its six substrates (D'Silva et al. 2011; Noma et al. 2011). Indeed, simple sequence inspection suggests no common theme that would direct Trm140 modS. cerevisiae tRNAs with $\mathrm{C}_{32}$.

Here we define the specificity of S. cerevisiae Trm140 by both in vivo and in vitro approaches. We show that there are two distinct modes of Trm 140 recognition of tRNA substrates for $\mathrm{m}^{3} \mathrm{C}_{32}$ modification. For $\mathrm{tRNA}^{\mathrm{Thr}}$ species, Trm140 reads the anticodon nucleotides and the $t^{6} \mathrm{~A}$ modification, whereas for tRNA ${ }^{\text {Ser }}$ species, recognition is achieved through seryl-tRNA synthetase (SerRS, encoded by SES1) and the V-loop region, as well as $i^{6} \mathrm{~A}_{37}$ or $\mathrm{t}^{6} \mathrm{~A}_{37}$.

\section{RESULTS}

\section{An XGU anticodon and $t^{6} A_{37}$ are necessary and sufficient for $\mathrm{m}^{3} \mathrm{C}$ modification of $\mathbf{R N A}^{\mathrm{Thr}}$ species}

To begin to elucidate the specificity of Trm140, we designed a scaffold based on $\mathrm{tRNA}^{\mathrm{Thr}(\mathrm{CGU})}$ [gene name: $t T(C G U)$ ] that would enable analysis of $\mathrm{m}^{3} \mathrm{C}$ in variants with this target scaffold independent of other tRNAs present in the cell. We altered the identity of base pairs 28:42 and 50:64 to allow us to analyze this tRNA species (tRNA ${ }^{\text {Thr(CGU) }}{ }_{28,50}$ ) with oligonucleotides spanning these residues (Fig. 1A). This variant was fully functional because an otherwise lethal $t T(C G U) \Delta$ strain was completely rescued upon integration of $t T(C G U)_{28,50}$, with 

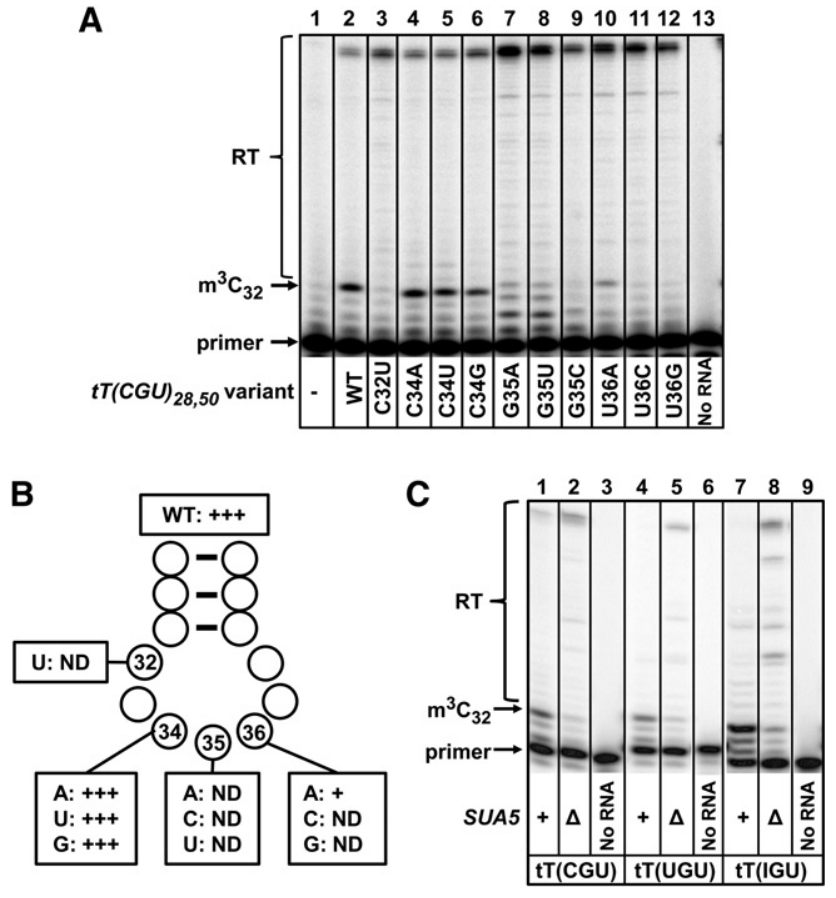

FIGURE 2. An $\mathrm{XGU}$ anticodon and $\mathrm{t}^{6} \mathrm{~A}_{37}$ are important for $\mathrm{m}^{3} \mathrm{C}$ modification of tRNA ${ }^{\text {Thr(CGU) }}$. (A) $\mathrm{G}_{35}$ and $\mathrm{U}_{36}$ of $\mathrm{tRNA}^{\mathrm{Thr}(\mathrm{CGU})}$ are required for $\mathrm{m}^{3} \mathrm{C}$ formation. Bulk RNA from strains containing integrated $t T$ $(C G U)_{28,50}$ variants with mutations as indicated were analyzed for $\mathrm{m}^{3} \mathrm{C}$ by primer extension, using a primer complementary to residues 51-37 of tRNA ${ }^{\operatorname{Thr}(\mathrm{CGU})}{ }_{28,50}$. The major read-through band on the top of the gel corresponds to the full-length tRNA. Note that for variants with $\mathrm{G}_{35}$ and $\mathrm{U}_{36}$, the primer extension is slightly displaced, presumably due to a different primer extension sequence. $(B)$ Summary of primer extension results of $\mathrm{m}^{3} \mathrm{C}$ modification in $A .+++$, WT levels of $\mathrm{m}^{3} \mathrm{C}$; +, low but detectable $\mathrm{m}^{3} \mathrm{C}$; ND, $\mathrm{m}^{3} \mathrm{C}$ not detected. $(C) \mathrm{t}^{6} \mathrm{~A}_{37}$ is important for $\mathrm{m}^{3} \mathrm{C}$ formation of tRNA ${ }^{\mathrm{Thr}}$ species. Bulk RNA from $S U A 5^{+}$and sua $5 \Delta$ cells was analyzed by primer extension with primers as indicated, to evaluate the importance of $\mathrm{t}^{6} \mathrm{~A}$ for $\mathrm{m}^{3} \mathrm{C}$ modification of tRNA ${ }^{\mathrm{Thr}}$ (CGU) tRNA $^{\text {Thr(UGU) }}$, and tRNA ${ }^{\text {Thr(IGU) }}$.

no discernable growth defect in the range of $30^{\circ} \mathrm{C}$ to $37^{\circ} \mathrm{C}$, compared to the corresponding strain bearing wild-type $t T$ $(C G U)$ at the same locus (Fig. 1B). The tRNA ${ }^{\mathrm{Thr}(\mathrm{CGU})}{ }_{28,50}$ variant was easily analyzed by primer extension independent of the wild-type tRNA ${ }^{\text {Thr(CGU) }}$ (Fig. 1C), and was efficiently modified to $\mathrm{m}^{3} \mathrm{C}$; the vast majority of this tRNA has $\mathrm{m}^{3} \mathrm{C}_{32}$, based on the prominent primer extension block at $\mathrm{N}_{33}$, compared to the relatively minor read-through signal (Fig. 1C), similar to the amount of $\mathrm{m}^{3} \mathrm{C}$ modification observed for wild-type $\mathrm{RNAA}^{\mathrm{Thr}(\mathrm{CGU})}$ (Fig. 2).

Since the $\mathrm{tRNA}^{\mathrm{Thr}}$ species bearing $\mathrm{m}^{3} \mathrm{C}_{32}$ all have similar anticodons (CGU, UGU, and IGU), we made and analyzed a set of yeast strains, each with an integrated tRNA ${ }^{\text {Thr(CGU) }}{ }_{28,50}$ variant bearing a single mutation in the anticodon loop (Fig. 2A,B). Primer extension analysis showed that alteration of $\mathrm{C}_{34}$ to other nucleotides resulted in retention of the major primer extension block at $\mathrm{N}_{33}$, indicative of $\mathrm{m}^{3} \mathrm{C}_{32}$. In contrast, substitution of residue $\mathrm{G}_{35}$ or $\mathrm{U}_{36}$ with each of the other nucleotides resulted in almost complete loss of $\mathrm{m}^{3} \mathrm{C}_{32}$. These results suggest that the conserved $\mathrm{G}_{35}$ and $\mathrm{U}_{36}$ residues in the anticodons of $\mathrm{tRNA}^{\mathrm{Thr}}$ species are required for $\mathrm{m}^{3} \mathrm{C}$ formation. As expected, substitution of $\mathrm{C}_{32}$ to $\mathrm{U}_{32}$ resulted in no primer extension stop.

Since $\mathrm{U}_{36}$ was important for $\mathrm{m}^{3} \mathrm{C}$ modification activity, and $\mathrm{U}_{36}$ is always followed by $\mathrm{t}^{6} \mathrm{~A}_{37}$ (Machnicka et al. 2013) or, as frequently occurs in yeast and some other organisms, a cyclized derivative of $\mathrm{t}^{6} \mathrm{~A}$ called $\mathrm{ct}^{6} \mathrm{~A}$ (Miyauchi et al. 2013), it was possible that $t^{6} \mathrm{~A}_{37}$ or $\mathrm{ct}^{6} \mathrm{~A}_{37}$ (collectively referred to as $\mathrm{t}^{6} \mathrm{~A}$ for simplicity) also had a role in $\mathrm{m}^{3} \mathrm{C}$ formation. To examine the contribution of $t^{6} \mathrm{~A}$ to $\mathrm{m}^{3} \mathrm{C}$ modification, we analyzed $\mathrm{m}^{3} \mathrm{C}$ levels in wild-type $\mathrm{tRNA}^{\mathrm{Thr}}$ species from an sua5 $\Delta$ strain, which lacks $\mathrm{t}^{6} \mathrm{~A}_{37}$ (El Yacoubi et al. 2009). The $\mathrm{m}^{3} \mathrm{C}$ levels in each of the three $\mathrm{tRNA}^{\mathrm{Thr}}$ species from the sua $5 \Delta$ strain were substantially reduced compared to those from the corresponding wild-type strain (Fig. 2C). This result suggested that $\mathrm{t}^{6} \mathrm{~A}_{37}$ was important, but not absolutely required, for $\mathrm{m}^{3} \mathrm{C}$ modification of the three $t R N A^{T h r}$ species in vivo, along with the required $\mathrm{G}_{35}-\mathrm{U}_{36}$ anticodon sequence.

To probe the connection between Trm140 tRNA modification specificity and Trm140 binding, we developed a pull-down assay. In a strain in which Trm140 was overproduced with a C-terminal tandem affinity purification tag (PT), we observed highly specific copurification of tRNA substrates. Trm140 was purified using IgG Sepharose in buffer conditions predicted to maintain native protein-RNA interactions, and then bound protein was washed once and eluted with protease to release Trm140 and retained RNAs. Northern analysis of the eluted tRNAs (Fig. 3A) showed highly efficient retention of Trm140 substrate tRNAs, including tRNA ${ }^{\mathrm{Thr}(\mathrm{IGU})}$, $\mathrm{tRNA}^{\mathrm{Thr}(\mathrm{UGU})} \mathrm{tRNA}^{\mathrm{Thr}(\mathrm{CGU})}$, relative to that in a vector control, whereas several nonsubstrate tRNAs examined did not copurify with Trm140, including $\mathrm{tRNA}^{\mathrm{Leu}(\mathrm{UAA})}$, tRNA ${ }^{\text {Phe(GAA)}}$, and $\mathrm{tRNA}^{\operatorname{Trp}(\mathrm{CCA})}$. Similar copurification results were obtained upon overproduction of ORF240 (Fig. 3B), the C-terminal domain of Trm 140 (comprising residues 277-628), which is necessary and sufficient for the methyltransferase activity in vivo (D'Silva et al. 2011); with either Trm140 or ORF240, we observed efficient retention of $\mathrm{tRNA}^{\mathrm{Thr}(\mathrm{IGU})}$, $\mathrm{tRNA}^{\mathrm{Ser}(\mathrm{GCU})}$, and tRNA $^{\text {Ser(UGA)/(CGA) }}$ (which were not distinguished by the hybridization probe we used), compared to the vector control. Because ORF240 was expressed at higher levels, had slightly stronger tRNA binding signals than Trm140, and also lacked the unnecessary N-terminal domain of Trm140, we continued binding experiments with ORF240. To quantify the specificity of ORF240 tRNA binding, we analyzed biological triplicate samples for ORF240 binding of a number of different tRNAs, using two washes before the release of bound protein by proteolytic cleavage. Under these conditions, tRNA $^{\text {Thr(CGU) }}$ bound very efficiently and reproducibly, whereas four nonsubstrate tRNAs did not, including tRNA ${ }^{\text {Phe(GAA), }}$ tRNA $^{\text {Lys(CUU) }}$, tRNA ${ }_{i}^{\text {Met }(C A U)}$, and tRNA ${ }^{\text {Ala(UGC) }}$ (Fig. 3C). For these and subsequent experiments we calculated binding 


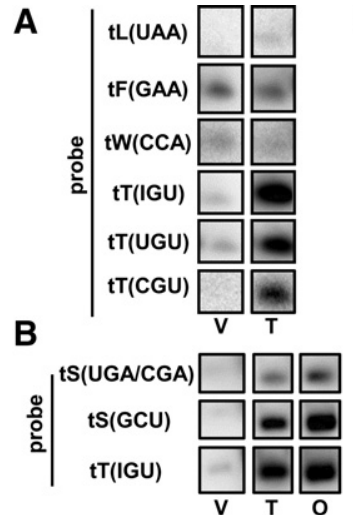

C

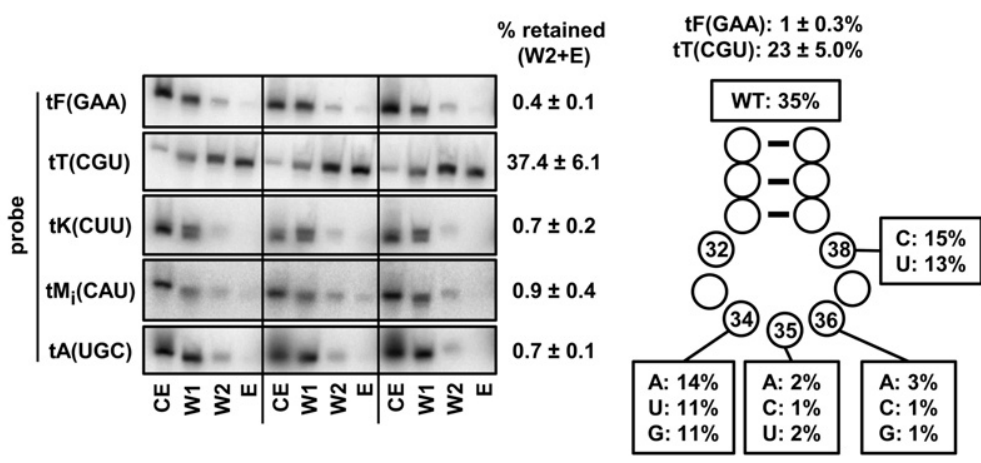

D

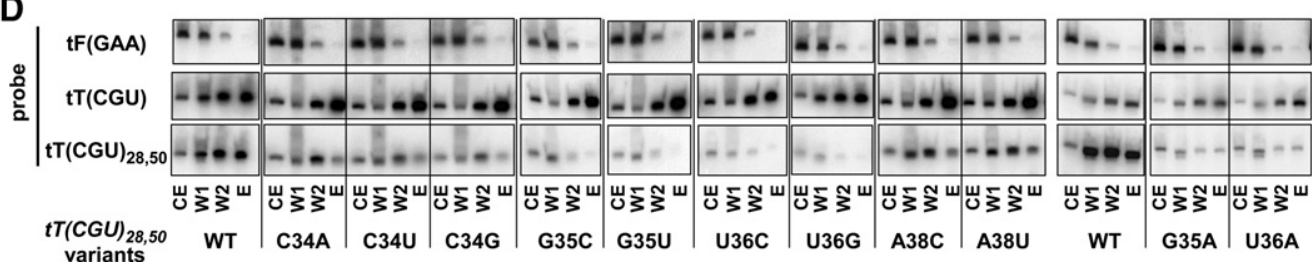

FIGURE 3. ORF240 binding of tRNA ${ }^{\text {Thr(CGU) }}$ requires $\mathrm{G}_{35}$ and $\mathrm{U}_{36}$. (A) Trm140 specifically binds tRNA ${ }^{\text {Thr }}$ substrates. Trm 140 was purified from a WT strain expressing TRM140-PT (or a vector control) by pull-down using IgG Sepharose, followed by a wash step and by elution of bound Trm140 by $3 \mathrm{C}$ protease treatment. Then, copurifying RNAs were resolved by PAGE, transferred to nitrocellulose, and analyzed by hybridization with probes as indicated. V, vector control; T, Trm140-PT. (B) ORF240 binds tRNA ${ }^{\text {Ser }}$ substrates as efficiently as Trm140. Trm140 and ORF240 were purified from WT strains expressing TRM140-PT or ORF240-PT (or a vector control) by pull-down, and copurifying tRNAs were analyzed as in A. O, ORF240-PT. (C) ORF240 binds specifically and reproducibly to tRNA ${ }^{\mathrm{Thr}(\mathrm{CGU})}$ and not to four nonsubstrate tRNAs. ORF240-PT was expressed in WT cells in biological triplicate and purified by pull-down, two wash steps, and 3C protease elution of bound ORF240, and copurifying tRNAs were analyzed as in $A$. The percentage of tRNA retained in the combined second wash and the elution step, relative to that in the crude extract was calculated for each tRNA, as indicated. CE, crude extract ( $0.4 \%$ loaded); W1, wash 1 (10\% loaded); W2, wash 2, (10\% loaded); E, elution (10\% loaded). (D) $\mathrm{G}_{35}$ and $\mathrm{U}_{36}$ of tRNA $^{\text {Thr(CGU) }}$ are important for binding of tRNA to ORF240. Strains containing integrated tRNA ${ }^{\text {Thr(CGU) }}{ }_{28,50}$ variants as indicated were grown and analyzed for ORF240 tRNA binding by the pull-down assay as described in $C$. (E) Schematic of pull-down results in $D$.

as the percentage of tRNA in the combined second wash and the elution step, relative to that in the crude extract, because it was apparent that $\mathrm{RRNA}^{\mathrm{Thr}(\mathrm{CGU})}$ was prominent in the second wash and the elution step, relative to the first wash, whereas the negative controls were much reduced in these fractions. These results establish that copurification of tRNA with Trm140 or ORF240 is a highly specific assay for substrate tRNA binding.

Consistent with our results from analysis of in vivo methyltransferase activity, we found that anticodon residues $\mathrm{G}_{35}$ and $\mathrm{U}_{36}$ were important for ORF240 binding as measured by this pull-down assay (Fig. 3D,E). Under these conditions, we observed reproducible copurification of wild-type tRNA $^{\operatorname{Thr}(\mathrm{CGU})}(23 \pm 5 \%)$ and reproducible lack of copurification of tRNA ${ }^{\text {Phe(GAA) }}(1 \pm 0.3 \%)$. For the tRNA ${ }^{\text {Thr(CGU) }}{ }_{28,50}$ variants, substitution of $G_{35}$ or $U_{36}$ with each of the other three nucleotides almost completely abolished the copurification of tRNA, whereas substitution of $\mathrm{C}_{34}$ with other nucleotides led to high levels of variant copurification. Based on these results, we conclude that Trm140 binds tRNAs with a $\mathrm{G}_{35}-\mathrm{U}_{36}$ anticodon. Since these are the same residues that are important for $\mathrm{m}^{3} \mathrm{C}$ modification, we infer that $\mathrm{m}^{3} \mathrm{C}$ modification is driven in large part by Trm140 tRNA binding. Because we found that copurification of the $\mathrm{C}_{34}$ variants was distinctly more efficient than the other three variants ( $35 \%$ versus $11 \%-14 \%$ ), we infer that $C_{34}$ is a modestly preferred wobble base nucleotide for ORF240 recognition. Residue 38 is likewise modestly influential for $\operatorname{Trm} 140 \mathrm{~m}^{3} \mathrm{C}$ modification, since the $\mathrm{A}_{38} \mathrm{U}$ or $\mathrm{A}_{38} \mathrm{C}$ mutations reduced binding modestly, from $35 \%$ to $13 \%-15 \%$, similar to the effects of $\mathrm{C}_{34}$ mutations.

To examine the sufficiency of $\mathrm{G}_{35}-\mathrm{U}_{36}-\mathrm{t}^{6} \mathrm{~A}_{37}$ for $\mathrm{m}^{3} \mathrm{C}$ formation, we replaced the anticodon of the nonsubstrate tRNA $^{\text {Phe(GAA) }}$ with a CGU anticodon and a $G_{37}$ A mutation to allow for $t^{6} \mathrm{~A}_{37}$ modification, and assayed the variant for $\mathrm{m}^{3} \mathrm{C}$ modification and tRNA binding by ORF240. As we did for tRNA ${ }^{\text {Thr(CGU) }}$ variants, we altered $2 \mathrm{bp}$ in the stem to allow for unique detection of the tRNA ${ }^{\text {Phe(GAA) }}$ variants; in this case, we flipped the 29:41 and 50:64 pairs to make tRNA $^{\text {Phe(GAA) }}{ }_{29,50}$ (Fig. 4A). ORF240 pull-down experiments resulted in efficient copurification (29\%) of the tRNA $^{\text {Phe(GAA) }}{ }_{29,50}[\mathrm{CGUA}]_{34-37}$ variant, but only background copurification (1\%) of tRNA ${ }^{\text {Phe(GAA) }}{ }_{29,50}\left[\mathrm{GAAG}_{34-37}\right.$ (Fig. $4 \mathrm{~B}, \mathrm{C})$. Consistent with the binding results, primer extension of RNA from cells containing the tRNA $^{\text {Phe(GAA) }}{ }_{29,50}$ $[\mathrm{CGUA}]_{34-37}$ variant revealed a strong primer extension block at $\mathrm{N}_{33}$, indicative of $\mathrm{m}^{3} \mathrm{C}$ modification (Fig. 4D). These binding and primer extension results of tRNA ${ }^{\mathrm{Phe}(\mathrm{GAA})}{ }_{29,50}$ 
A
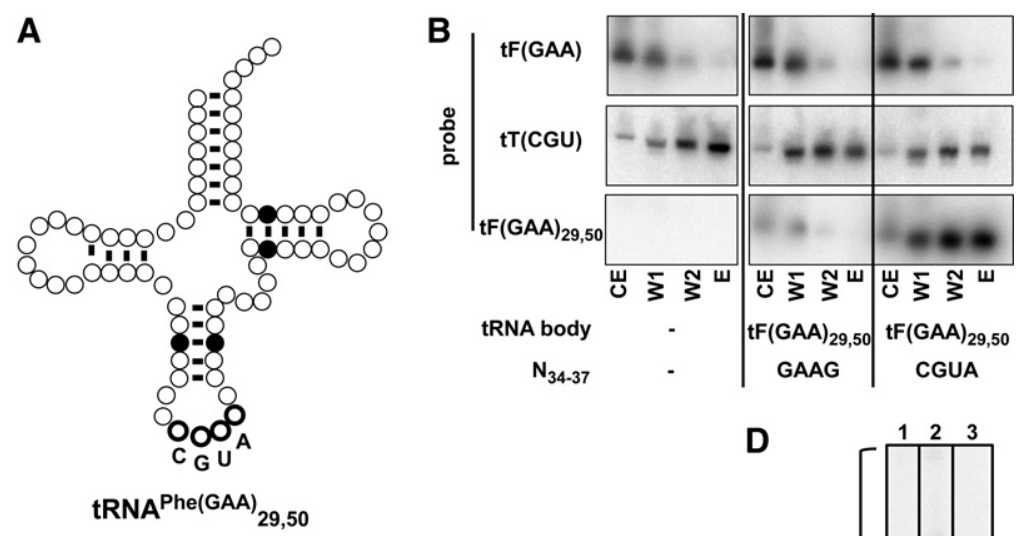

C

\% tRNA retained
\begin{tabular}{|c|c|c|c|}
\hline \multirow{2}{*}{$\begin{array}{c}\text { tRNA } \\
\text { variant }\end{array}$} & tRNA & tF(GAA) 29,50 & tF(GAA) $)_{29,50}$ \\
\cline { 2 - 4 } & $\mathrm{N}_{34-37}$ & GAAG & CGUA \\
\hline \multirow{3}{*}{ probe } & $\mathrm{tF}(\mathrm{GAA})$ & 0.6 & 0.5 \\
\cline { 2 - 4 } & $\mathrm{tT}(\mathrm{CGU})$ & 40 & 36 \\
\cline { 2 - 4 } & $\mathrm{tF}(\mathrm{GAA}) 29,50$ & 1 & 29 \\
\hline
\end{tabular}

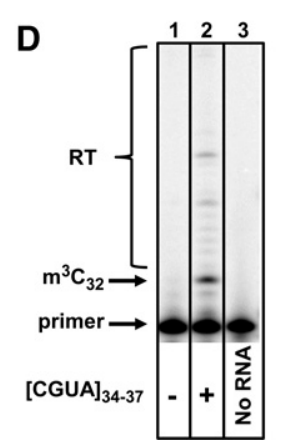

FIGURE 4. An XGU anticodon and $t^{6} \mathrm{~A}_{37}$ are sufficient for ORF240 binding and for $\mathrm{m}^{3} \mathrm{C}$ modification of tRNA ${ }^{\text {Phe }}$. (A) Schematic of tRNA ${ }^{\text {Phe(GAA) }}{ }_{29,50}$ variant. The secondary structure of tRNA ${ }^{\text {Phe }}$ is shown, with highlighting of base pairs 29:41 and 50:64 that were flipped, and bold outline of residues $\mathrm{N}_{34-37}$ that were changed from GAAG to CGUA. (B) A CGU anticodon and $t^{6} \mathrm{~A}_{37}$ are sufficient for binding of tRNA ${ }^{\text {Phe }}$ to ORF240. Strains with integrated $t F$ $(G A A)_{29,50}$ variants as indicated were analyzed by the ORF240 tRNA pull-down assay as described in Figure 3C. $(C)$ Summary of pull-down results in B. (D) A CGU anticodon and $\mathrm{t}^{6} \mathrm{~A}_{37}$ are sufficient for $\mathrm{m}^{3} \mathrm{C}$ modification of $\mathrm{tRNA}{ }^{\text {Phe }}$. Bulk RNA from strains without (lane 1) or with a tRNA ${ }^{\text {Phe(GAA) }}{ }_{29,50}[\mathrm{CGUA}]_{34-37}$ variant (lane 2) was analyzed by primer extension for $\mathrm{m}^{3} \mathrm{C}$, using a primer complementary to residues $52-36$ of the variant. Lane 3, primer alone. indicate that a CGU anticodon and $\mathrm{A}_{37}$ (presumably modified to $\mathrm{t}^{6} \mathrm{~A}$ ) are sufficient for $\mathrm{m}^{3} \mathrm{C}$ modification of $\mathrm{tRNA}{ }^{\text {Phe }}$ (GAA) and establish that this sequence is an identity element for the modification.

\section{$t^{6} A_{37}$ and $i^{6} A_{37}$ are important for $m^{3} C$ modification of tRNA ${ }^{\text {Ser }}$ species}

Unlike the three $\mathrm{tRNA}^{\text {Thr }}$ Trm140 substrates, which all share the anticodon residues $G_{35}$ and $U_{36}$, the three tRNA ${ }^{\text {Ser }}$ substrates tRNA ${ }^{\text {Ser(CGA) }}$, tRNA $^{\text {Ser(UGA) }}$, and tRNA ${ }^{\operatorname{Ser}(\mathrm{GCU})}$ do not share any anticodon residues with one another, and therefore the major Trm140 specificity determinant for tRNA ${ }^{\text {Ser }}$ must be elsewhere. Furthermore, although $t^{6} \mathrm{~A}_{37}$ is important for Trm140 modification of tRNA $^{\text {Thr }}$, only tRNA ${ }^{\text {Ser(GCU) }}$ has $t^{6} \mathrm{~A}$, whereas tRNA ${ }^{\text {Ser(CGA) }}$ and tRNA ${ }^{\operatorname{Ser}(\mathrm{UGA})}$ have $i^{6} A_{37}$.

Consistent with the importance of $\mathrm{t}^{6} \mathrm{~A}$ for $\mathrm{m}^{3} \mathrm{C}$ modification of $\mathrm{RNA}^{\mathrm{Thr}}$ species, we found that the $\mathrm{m}^{3} \mathrm{C}$ modification level of tRNA ${ }^{\mathrm{Ser}(\mathrm{GCU})}$ was substantially lower in the sua5 $\Delta$ strain compared to the WT strain (Fig. 5A). We also found that $\mathrm{m}^{3} \mathrm{C}$ was substantially reduced in
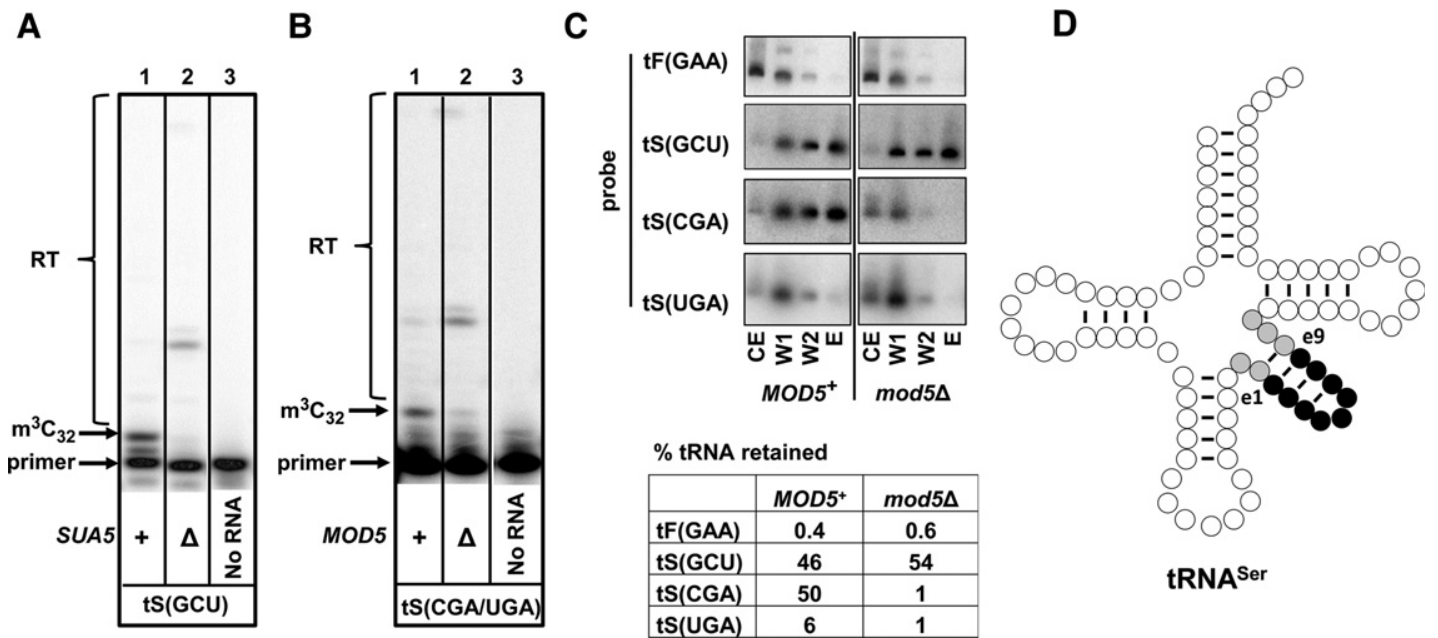

FIGURE 5. $\mathrm{t}^{6} \mathrm{~A}_{37}$ and $\mathrm{i}^{6} \mathrm{~A}_{37}$ are important for $\mathrm{m}^{3} \mathrm{C}$ modification of $\mathrm{tRNA} \mathrm{ser}^{\text {Ser }}$ species. $(A) \mathrm{t}^{6} \mathrm{~A}_{37}$ is important for $\mathrm{m}^{3} \mathrm{C}$ modification of tRNA ${ }^{\text {Ser }}$ (GCU). Bulk RNA from SUA5 ${ }^{+}$and sua5 $\Delta$ cells was analyzed by primer extension with a primer annealing to residue e7-35 of tRNA ${ }^{\text {Ser(GCU) }}$. (B) $\mathrm{i}^{6} \mathrm{~A}_{37}$ is important for $\mathrm{m}^{3} \mathrm{C}$ modification of tRNA ${ }^{\text {Ser(UGA) }}$ and tRNA ${ }^{\text {Ser(CGA) }}$. Bulk RNA from MOD5 $5^{+}$and mod5 cells was analyzed by primer extension with a primer annealing to residue e8-36 of tRNA ${ }^{\operatorname{Ser}(\mathrm{CGA})}$. (C) $\mathrm{i}^{6} \mathrm{~A}_{37}$ is important for tRNA ${ }^{\text {Ser(CGA) }}$ binding to ORF240. ORF240-PT was expressed in $M O D 5^{+}$and $\bmod 5 \Delta$ strains, and ORF240 tRNA binding was analyzed by the IgG Sepharose pull-down assay as described in Figure 3C. (D) Schematic of tRNA ${ }^{\text {Ser }}$ with highlighting of the V-loop containing residues $\mathrm{N}_{\mathrm{el}-\mathrm{e} 9}$ (black) and five other nucleotides (gray). 
tRNA $A^{\mathrm{Ser}(\mathrm{CGA}) /(\mathrm{UGA})}$ in a $\bmod 5 \Delta$ strain, which lacks the $\mathrm{i}^{6} \mathrm{~A}_{37}$ modification (Fig. 5B; Dihanich et al. 1987), as also found for the $\mathrm{m}^{3} \mathrm{C}$ modification of tRNA ${ }^{\text {Ser }}$ substrates in $S$. pombe (Arimbasseri et al. 2016). Thus, it appears that both $\mathrm{t}^{6} \mathrm{~A}$ and $i^{6} \mathrm{~A}$ contribute to efficient $\mathrm{m}^{3} \mathrm{C}$ modification.

We further showed that $\mathrm{i}^{6} \mathrm{~A}_{37}$ was important for $\mathrm{tRNA}{ }^{\text {Ser }}$ (CGA) binding to ORF240 (Fig. 5C). While ORF240 bound $50 \%$ of the $\mathrm{tRNA}^{\mathrm{Ser}(\mathrm{CGA})}$ in a $M O D 5^{+}$strain, it only bound $1 \%$ of this tRNA in a mod5 $\Delta$ strain. Similarly, although tRNA $^{\text {Ser(UGA) }}$ bound more weakly to ORF240 in a MOD5 ${ }^{+}$ strain $(6 \%)$, this binding was undetectable in a $\bmod 5 \Delta$ strain. As expected, binding of tRNA ${ }^{\operatorname{Ser}(\mathrm{GCU})}$ was not affected in the $\bmod 5 \Delta$ strain, because this tRNA is not a Mod5 substrate. Because $i^{6} \mathrm{~A}_{37}$ is crucial for ORF240 binding and for $\mathrm{m}^{3} \mathrm{C}$ modification of $\mathrm{tRNA}^{\mathrm{Ser}(\mathrm{CGA})}$ and $\mathrm{tRNA}^{\mathrm{Ser}(\mathrm{UGA})}$, we infer that ORF240 binding is important for $\mathrm{m}^{3} \mathrm{C}$ formation.

Although $i^{6} \mathrm{~A}$ and $\mathrm{t}^{6} \mathrm{~A}$ are important for recognition of tRNA $^{\text {Ser }}$ substrates by Trm140, they could not be the sole determinants for $\mathrm{m}^{3} \mathrm{C}$ modification, since there are nine other S. cerevisiae tRNAs with both $\mathrm{C}_{32}$ and $\mathrm{t}^{6} \mathrm{~A}_{37}$ that lack the $\mathrm{m}^{3} \mathrm{C}$ modification, and one other tRNA with $\mathrm{C}_{32}$ and $\mathrm{i}^{6} \mathrm{~A}$ that lacks $\mathrm{m}^{3} \mathrm{C}$.

\section{Ses1 copurifies with Trm140}

One unique feature of tRNA ${ }^{\mathrm{Ser}}$ species that could in principle be important for $\mathrm{m}^{3} \mathrm{C}$ modification is the distinctive long $\mathrm{V}$ loop. In yeast, the tRNA ${ }^{\text {Ser }} \mathrm{V}$-loops are all $14 \mathrm{nt}$ long (Fig. $5 \mathrm{D})$, whereas the only other tRNAs with a long V-loop are members of the tRNA ${ }^{\text {Leu }}$ family, with V-loops of 13 or 15 nt. Trm140 could recognize the distinctive tRNA ${ }^{\text {Ser }}$ V-loop, or Trm140 might cooperate with other proteins such as seryl-tRNA synthetase, Ses1, to recognize the V-loop. Ses1 is known to recognize a V-loop of the appropriate length for its charging activity (Himeno et al. 1997).

To define proteins that interact with Trm140, we purified ORF240 under identical conditions to those we used for copurification of tRNAs, and compared the copurifying polypeptides with those of the negative control glutaminyl-tRNA synthetase, encoded by GLN4. Coomassie staining revealed three polypeptide bands that copurified with ORF240, one of which, labeled A, appeared to be shared by Gln4 (Fig. $6 \mathrm{~A}$ ). Mass spectrometry analysis showed that the major proteins in band A from Ses1 and Gln4 were the same (heat shock protein Ssa1, Ssa2, and Ssc1), and that band C corresponded to ORF240 breakdown polypeptides. However, the major polypeptides in band B were Ses1 and YNL040W, with convincing Mascot scores of 1737 and 660, respectively, and these proteins were not found at all in the corresponding Gln4 purification. Examination of a ynl040w $\Delta$ strain showed no alteration of $\mathrm{m}^{3} \mathrm{C}$ levels of tRNA ${ }^{\text {Thr(IGU) }}$ or tRNA ${ }^{\mathrm{Ser}(\mathrm{UGA}) /(\mathrm{CGA})}$. We therefore focused on Ses1.

We found that Trm140 interacted with Ses1 in wild-type cells, because affinity purification of Trm140 with a chromosomal C-terminal MORF tag (Trm140-cMORF) resulted in

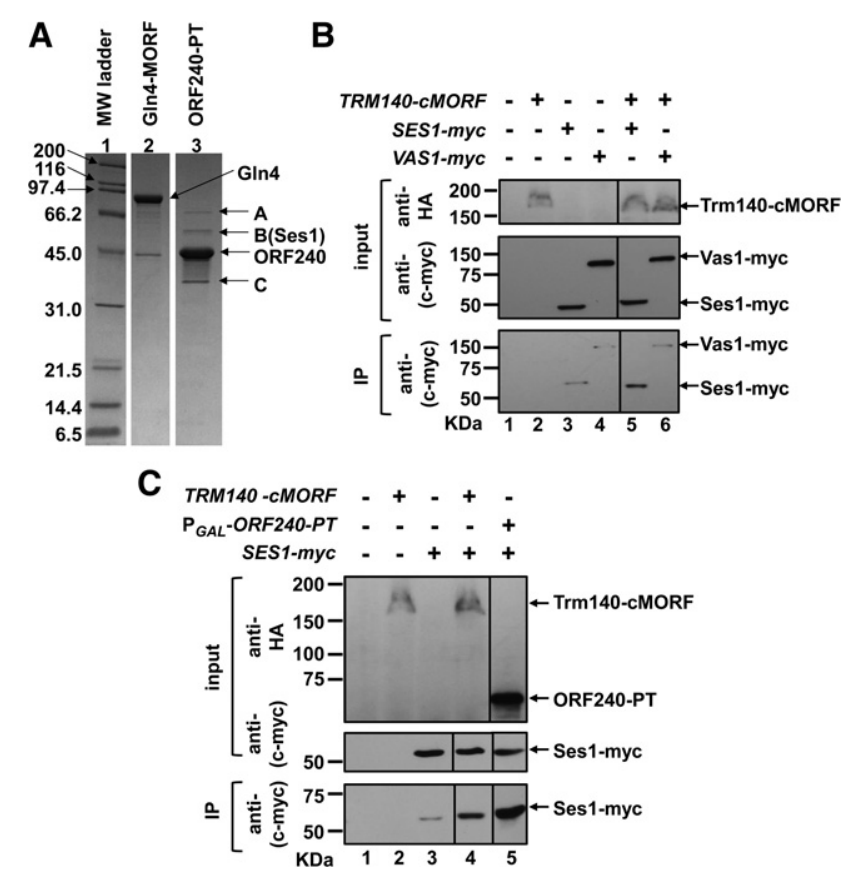

FIGURE 6. Trm140 interacts with Ses1. (A) SDS-PAGE analysis reveals three polypeptide bands that copurify with Trm140. Strains containing either $\mathrm{P}_{G A L^{-}}$ORF240-PT or $\mathrm{P}_{G A L^{-}}$GLN4-MORF were grown as described in Materials and Methods, ORF240 and Gln4 were affinity purified under conditions identical to those used for pull-down assays, and proteins were analyzed by SDS-PAGE and Coomassie staining. Three distinct copurifying bands that were found in the ORF240 preparation (lane 3) are labeled A-C. (B) Chromosomally expressed Ses1-Myc and Trm140-cMORF interact. Trm140 was affinity purified from crude extracts of the indicated strains, using IgG Sepharose and $3 \mathrm{C}$ protease cleavage. Crude extract (input) was subjected to immunoblot analysis with anti-HA and anti-(c-myc) antibody, and IgG-purified protein (immunoprecipitate, IP) was analyzed by immunoblot with anti-(c-myc) antibody. $(C)$ Overproduction of ORF240-PT results in increased copurification of Ses1. Trm 140 was purified from a chromosomally tagged Trm140-cMORF strain, ORF240 was purified from a strain overexpressing ORF240-PT, and the amount of copurifying Ses1 was compared by immunoblot, as described in $B$.

copurification of chromosomally tagged Ses1-myc (Fig. 6B, cf. lanes 3 and 5), but no obvious copurification of the control Vas1-Myc (valyl-tRNA synthetase) (Fig. 6B, lanes 4,6). Moreover, overproduction of ORF240-PT under $\mathrm{P}_{G A L}$ control resulted in copurification of substantially increased amounts of Ses1-myc (Fig. 6C, lanes 4,5). This interaction of Trm140 with Ses 1 suggested the possibility that Ses 1 might have a role in the $\mathrm{m}^{3} \mathrm{C}$ modification reaction.

\section{Ses1 stimulates $\mathrm{m}^{3} \mathrm{C}$ formation of tRNA ${ }^{\text {Ser }}$ species}

To determine if Ses 1 had a role in $\mathrm{m}^{3} \mathrm{C}$ modification, we examined the methyltransferase activity of Trm 140 in vitro. We expressed and purified $\mathrm{His}_{6}$-ORF240 from Escherichia coli and assayed its activity with tRNA purified from a trm140D strain. After incubation of ORF240 with S-adenosylmethionine (SAM) and tRNA, we analyzed $\mathrm{m}^{3} \mathrm{C}$ modification by primer extension in the presence of ddTTP, and calculated 
TABLE 1. Summary of the efficiency of ORF $240 \quad \mathrm{~m}^{3} \mathrm{C}$ methyltransferase activity on tRNA ${ }^{\text {Thr }}$ and tRNA ${ }^{\text {Ser }}$ substrates

\begin{tabular}{lcc}
\hline tRNA $^{\mathrm{a}}$ & ORF240 $_{1 / 2}(\mu \mathrm{M})$ & $\begin{array}{c}\text { ORF240 } \\
\text { with } 1.5 \mu \mathrm{M})\end{array}$ \\
\hline tRNA $^{\text {Thr(IGU) }}$ & 0.02 & 0.02 \\
tRNA $^{\text {Thr(UGU) }}$ & 0.02 & - \\
tRNA $^{\text {Thr(CGU) }}$ & 0.02 & - \\
tRNA $^{\text {Ser(GCU) }}$ & 0.05 & 0.02 \\
tRNA $^{\text {Ser(CGA) }}$ & 0.3 & 0.02 \\
tRNA $^{\text {Ser(UGA) }}$ & $\sim 15^{\mathrm{b}}$ & 0.3 \\
tRNA $^{\text {Tyr(GUA) }}$ & $>30^{\mathrm{b}}$ & $>30^{\mathrm{b}}$ \\
\hline
\end{tabular}

${ }^{\mathrm{a}} 0.35 \mathrm{pmol}$ assayed in $20 \mu \mathrm{L}$.

bstimated from activity at $2.5 \mu \mathrm{M}$ ORF240.

the efficiency of $\mathrm{m}^{3} \mathrm{C}$ modification based on the intensities of the primer extension blocks at $\mathrm{U}_{33}$, due to $\mathrm{m}^{3} \mathrm{C}_{32}$, and at $\mathrm{A}_{31}$, due to read-through and termination by ddTTP incorporation. Using this assay, we found that the three tRNA ${ }^{\text {Thr }}$ species were equally efficiently modified by ORF240 (Table 1 ; Fig. 7A,B), in each case requiring $\sim 0.02 \mu \mathrm{M}$ ORF240 for one-half-maximal modification $\left(\mathrm{ORF} 240_{1 / 2}\right)$. In contrast, ORF240 was very inefficient at $\mathrm{m}^{3} \mathrm{C}$ modification of tRNA $^{\text {Ser(UGA) }}$ and tRNA ${ }^{\text {Ser(CGA) }}$, with ORF240 $0_{1 / 2}$ values of $\sim 15 \mu \mathrm{M}$ and $\sim 0.3 \mu \mathrm{M}$, respectively, while the ORF240 ${ }_{1 / 2}$ value was $\sim 0.05 \mu \mathrm{M}$ for tRNA ${ }^{\text {Ser(GCU) }}$. As anticipated, no $\mathrm{m}^{3} \mathrm{C}$ was detected upon ORF240 assay of tRNA ${ }^{\operatorname{Tyr}(\mathrm{GUA})}$, which normally bears an unmodified $\mathrm{C}_{32}$ (Table 1 ).

Consistent with an important biological role for the interaction of Trm140 with Ses1, we found that purified Ses1 stimulated the $\operatorname{Trm} 140 \mathrm{~m}^{3} \mathrm{C}$ modification activity on $\mathrm{tRNA}^{\text {Ser }}$ species in vitro. Using Ses1 purified from a

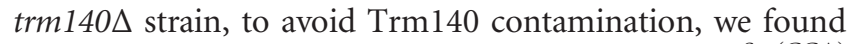
that $1.5 \mu \mathrm{M}$ Ses1 reduced the ORF $240_{1 / 2}$ of $\mathrm{tRNA}{ }^{\mathrm{Ser}(\mathrm{CGA})}$ from $\sim 0.3 \mu \mathrm{M}$ to $\sim 0.02 \mu \mathrm{M}$, of tRNA ${ }^{\operatorname{Ser}(\mathrm{UGA})}$ from $\sim 15 \mu \mathrm{M}$ to $\sim 0.3 \mu \mathrm{M}$, and of tRNA ${ }^{\text {Ser(GCU) }}$ from $0.05 \mu \mathrm{M}$ to $0.02 \mu \mathrm{M}$, but had little or no effect on tRNA ${ }^{\operatorname{Thr}(\mathrm{IGU})}$ or tRNA $^{\text {Tyr(GUA) }}$ (Table 1; Fig. 8A,B).
Consistent with these in vitro results, we observed Ses1 stimulation of $\mathrm{m}^{3} \mathrm{C}$ modification in vivo. To address this question, we assayed $\mathrm{m}^{3} \mathrm{C}$ modification after overproduction of Ses1-MORF in a mod5 $\Delta$ strain, in which $\mathrm{m}^{3} \mathrm{C}_{32}$ modification of tRNA ${ }^{\mathrm{Ser}(\mathrm{CGA}) /(\mathrm{UGA})}$ was reduced due to lack of $\mathrm{i}^{6} \mathrm{~A}$ (Fig. 5B). We found that overproduction of Ses1 resulted in a substantial increase in $\mathrm{m}^{3} \mathrm{C}$ levels of tRNA ${ }^{\mathrm{Ser}(\mathrm{CGA}) /(\mathrm{UGA})} \mathrm{rel}-$ ative to that in the vector control, from $2 \%$ to $24 \%$ (Fig. 9A). Overproduction of ORF240 also improved the $\mathrm{m}^{3} \mathrm{C}$ modification, consistent with the fact that $\mathrm{i}^{6} \mathrm{~A}$ was important for ORF240 binding. As expected, the $\mathrm{m}^{3} \mathrm{C}$ levels of tRNA ${ }^{\text {Thr }}$ (IGU), which has $\mathrm{t}^{6} \mathrm{~A}$ and not $\mathrm{i}^{6} \mathrm{~A}$, were not affected in the $\bmod 5 \Delta$ strain or by overproduction of either Ses1 or ORF240.

To determine whether the important region for $\mathrm{m}^{3} \mathrm{C}$ modification of tRNA ${ }^{\mathrm{Ser}}$ species was the V-loop, we tested the modification of a chimeric tRNA ${ }^{\text {Leu }}$ species with a V-loop based on $\mathrm{tRNA}^{\mathrm{Ser}}$. We constructed a variant with the body sequence of tRNA ${ }^{\mathrm{Leu}(\mathrm{UAA})}$, the anticodon UGA, and $\mathrm{A}_{37}$, called variant M1 (Fig. 9B). This M1 variant was not a substrate for $\mathrm{m}^{3} \mathrm{C}$ modification (Fig. 9C, lane 2). However, the variant M2, which differs from $\mathrm{M} 1$ due to replacement of the $\mathrm{V}$-loop with that of tRNA ${ }^{\mathrm{Ser}(\mathrm{GCU})}$, was significantly modified to $\mathrm{m}^{3} \mathrm{C}_{32}$ (Fig. 9C, lane 5). This result shows that the tRNA ${ }^{\text {Ser }} \mathrm{V}$-loop is sufficient to confer $\mathrm{m}^{3} \mathrm{C}_{32}$ modification of the $\mathrm{M} 1$ variant in the context of this tRNA species.

\section{DISCUSSION}

We have provided evidence here that $S$. cerevisiae $\operatorname{Trm} 140$ has two strikingly different recognition modes for tRNA $\mathrm{m}^{3} \mathrm{C}$ modification. Trm140 explicitly recognizes the XGU anticodon and $t^{6} \mathrm{~A}_{37}$ of $\mathrm{tRNA}^{\mathrm{Thr}}$ species as an identity element for $\mathrm{m}^{3} \mathrm{C}$ modification in vivo. Thus, substitution of either $\mathrm{G}_{35}$ or $\mathrm{U}_{36}$ of $\mathrm{tRNA}^{\mathrm{Thr}(\mathrm{CGU})}$ with any other residue resulted in the complete absence of $\mathrm{m}^{3} \mathrm{C}$ modification, and removal of $t^{6} \mathrm{~A}$ substantially reduced $\mathrm{m}^{3} \mathrm{C}$ modification, whereas introduction of a CGU anticodon and $\mathrm{A}_{37}$ to $\mathrm{tRNA}^{\text {Phe }}$ resulted in efficient $\mathrm{m}^{3} \mathrm{C}$ modification in vivo. Consistent with these
A

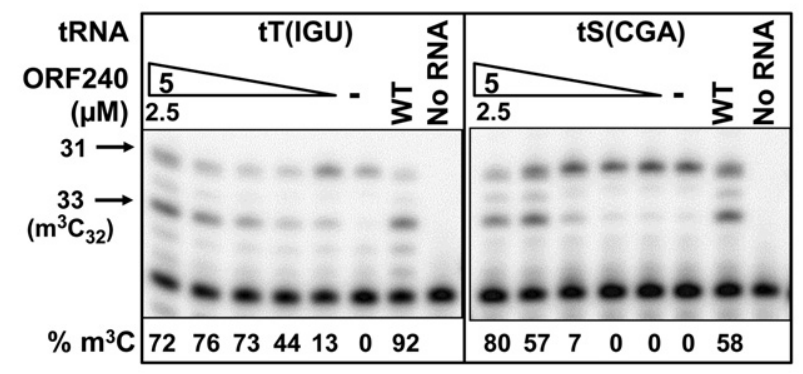

B

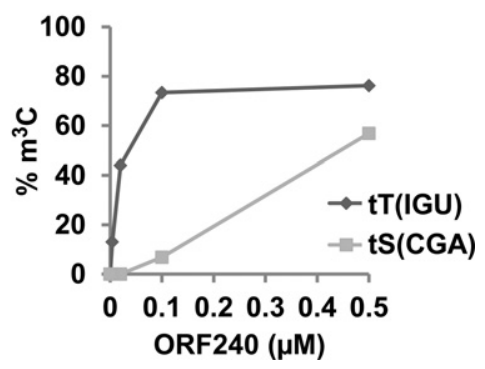

FIGURE 7. ORF240 catalyzes efficient $\mathrm{m}^{3} \mathrm{C}$ modification of $\mathrm{tRNA}{ }^{\mathrm{Thr}(\mathrm{IGU})}$ but inefficient modification of tRNA ${ }^{\mathrm{Ser}(\mathrm{CGA})}$. (A) Titration of ORF240 $\mathrm{m}^{3} \mathrm{C}$

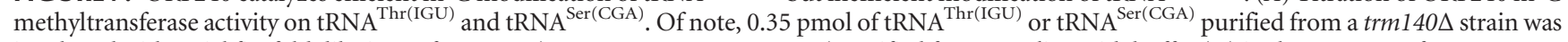
incubated with serial fivefold dilutions of ORF240 $(2.5,0.5,0.1,0.02,0.004 \mu \mathrm{M})$ purified from $E$. coli or with buffer $(-)$ in the presence of SAM at $30^{\circ} \mathrm{C}$ for $1 \mathrm{~h}$, and tRNA was analyzed for $\mathrm{m}^{3} \mathrm{C}$ by primer extension in the presence of ddTTP, as described in Materials and Methods. $(B)$ Plot of $\mathrm{m}^{3} \mathrm{C}$ modification as a function of the concentration of ORF240 in $A$. 


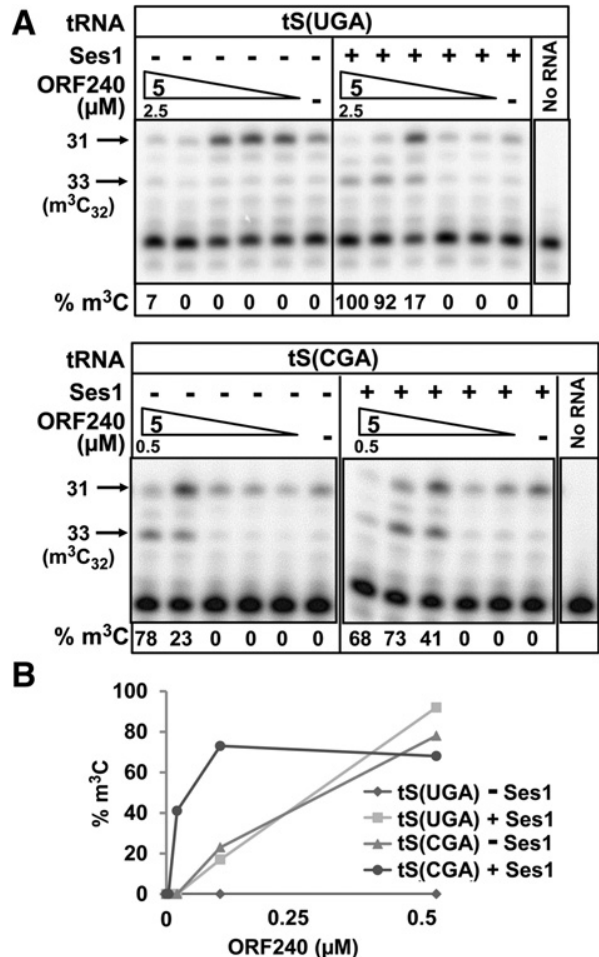

FIGURE 8. Ses 1 stimulates ORF $240 \mathrm{~m}^{3} \mathrm{C}$ modification of tRNA ${ }^{\mathrm{Ser}(\mathrm{UGA})}$ and tRNA ${ }^{\text {Ser(CGA) }}$. (A) Effect of Ses1 on the titration of ORF $240 \mathrm{~m}^{3} \mathrm{C}$ methyltransferase activity on tRNA ${ }^{\text {Ser(CGA) }}$ and tRNA ${ }^{\text {Ser(UGA) }}$. Of note, 0.35 pmol of tRNA $^{\text {Ser(UGA) }}$ and tRNA ${ }^{\text {Ser(CGA) }}$ purified from a trm $140 \Delta$ strain was assayed for $\mathrm{m}^{3} \mathrm{C}$ formation by ORF240 in the presence or ab-

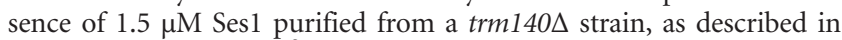
Figure 7A. (B) Plot of $\mathrm{m}^{3} \mathrm{C}$ modification as a function of the concentration of ORF240 in $A$.

results, ORF240 expressed and purified from E. coli efficiently catalyzed modification of all three $\mathrm{tRNA}^{\mathrm{Thr}}$ species, but not tRNA $^{\text {Tyr }}$.

In contrast, the CGA, UGA, and GCU anticodons of the three $t R N A^{\text {Ser }}$ species that are modified with $\mathrm{m}^{3} \mathrm{C}_{32}$ do not have a common feature, and Trm140 recognition of these species is instead propelled by interaction with Ses1 and the tRNA $^{\text {Ser }} \mathrm{V}$-loop, as well as by $i^{6} \mathrm{~A}_{37}$ of $\mathrm{tRNA}^{\mathrm{Ser}(\mathrm{CGA})}$ and tRNA ${ }^{\text {Ser(UGA) }}$, and $t^{6} A_{37}$ of $t R N A^{\text {Ser(GCU) }}$. Thus, purified Ses 1 stimulated the efficiency of ORF $240 \mathrm{~m}^{3} \mathrm{C}$ modification of tRNA $^{\text {Ser(CGA) }}$, decreasing ORF $240_{1 / 2}$ by 20 -fold, to a value

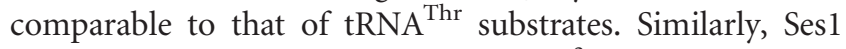
stimulated the efficiency of ORF $240 \mathrm{~m}^{3} \mathrm{C}$ modification of

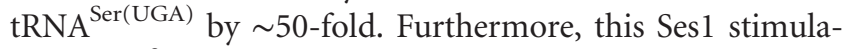
tion of $\mathrm{m}^{3} \mathrm{C}$ modification was also observed in vivo, since Ses1 overproduction significantly increased $\mathrm{m}^{3} \mathrm{C}$ modification of $\mathrm{tRNA}^{\mathrm{Ser}(\mathrm{CGA}) /(\mathrm{UGA})}$ in a strain lacking $\mathrm{i}^{6} \mathrm{~A}$.

Our results suggest that $\mathrm{m}^{3} \mathrm{C}$ modification activity is driven in part by binding. We showed that all six known Trm 140 substrate tRNAs copurified with Trm140 or ORF240, whereas each of six tested nonsubstrate tRNAs did not copurify. We also showed that ORF240 binding of $\mathrm{tRNA}^{\text {Thr }}$ anticodon loop variants tracked perfectly with $\mathrm{m}^{3} \mathrm{C}$ modification, since all six possible variants with mutations in $\mathrm{G}_{35}$ or $\mathrm{U}_{36}$ lacked modification and also did not bind, whereas each of the three variants with mutations in $\mathrm{C}_{34}$ were modified and bound efficiently, although not as efficiently as with $\mathrm{C}_{34}$. Furthermore, ORF240 bound tRNA ${ }^{\text {Phe }}$ efficiently only when its anticodon was altered to $\mathrm{CGU}-\mathrm{A}_{37}$, correlated with $\mathrm{m}^{3} \mathrm{C}$ modification, and $i^{6} \mathrm{~A}_{37}$ was important for binding of $\mathrm{tRNA}^{\mathrm{Ser}(\mathrm{CGA})}$ to ORF240 as well as for $\mathrm{m}^{3} \mathrm{C}$ modification. These results suggest a modular binding mechanism to explain substrate specificity, in which contributions are made by $\mathrm{G}_{35}, \mathrm{U}_{36}$, $i^{6} A_{37}$, or $t^{6} A_{37}$, and the $\mathrm{V}$-loop, as well as $\mathrm{C}_{34} \cdot \mathrm{C}_{34}$ is favored over other $\mathrm{N}_{34}$ residues based on preferential binding of $\mathrm{tRNA}^{\mathrm{Thr}} \mathrm{C}_{34}$ variants and preferential binding of tRNA $^{\text {Ser(CGA) }}$ compared to tRNA ${ }^{\text {Ser(UGA) }}$ since these two tRNAs are identical other than $\mathrm{U}_{34}$ and the $\mathrm{N}_{28}-\mathrm{N}_{42}$ pair. This preferential binding of $\mathrm{tRNA}^{\mathrm{Ser}(\mathrm{CGA})}$ relative to that of tRNA ${ }^{\text {Ser(UGA) }}$ is also consistent with the preferential ORF240 modification activity of tRNA ${ }^{\text {Ser(CGA) }}$ compared to tRNA $^{\text {Ser(UGA) }}$.

Proteins like Trm140 that bind nucleic acids by two very different modes are rare. Notable examples include TFIIIA, which recognizes $5 \mathrm{~S}$ promoter DNA and 5S RNA using distinctive zinc fingers (Nolte et al. 1998; Lu et al. 2003; Hall 2005), and phage $\lambda$ integrase protein, which recognizes two different DNA sequences with different domains (Moitoso de Vargas et al. 1988). It is intriguing that bovine mitochondrial Ses 1 recognizes $\mathrm{tRNA}^{\text {Ser }}$ substrates with and without a D-stem-loop by different mechanisms, but involving the same region of the T-loop (Shimada et al. 2001); the different modes of Trm140 recognition of $\mathrm{tRNA}^{\mathrm{Thr}}$ compared to tRNA $^{\text {Ser(CGA) }}$ and tRNA ${ }^{\text {Ser(UGA) }}$ also appear to involve common elements including $\mathrm{C}_{34}$ and $i^{6} \mathrm{~A}_{37}$ or $\mathrm{t}^{6} \mathrm{~A}_{37}$, as well as the specific involvement of Ses1 for $\mathrm{tRNA}^{\mathrm{Ser}}$ and $\mathrm{G}_{35}-\mathrm{U}_{36}$ for tRNA $^{\text {Thr }}$.

The observation that $i^{6} \mathrm{~A}$ and $t^{6} \mathrm{~A}$ are important for $\mathrm{m}^{3} \mathrm{C}$ modification is a clear demonstration of ordered modification circuitry in the anticodon loops of $\mathrm{tRNA}^{\mathrm{Thr}}$ and $\mathrm{tRNA}^{\mathrm{Ser}}$, in which either $\mathrm{A}_{37}$ modification drives $\mathrm{m}^{3} \mathrm{C}$ formation. Maraia and coworkers recently observed that $i^{6} \mathrm{~A}$ modification was important for $\mathrm{m}^{3} \mathrm{C}_{32}$ modification in $\mathrm{tRNA}{ }^{\mathrm{Ser}}$ species of $S$. pombe and speculated that $\mathrm{t}^{6} \mathrm{~A}$ modification would be important for $\mathrm{m}^{3} \mathrm{C}_{32}$ modification of $\mathrm{tRNA}^{\mathrm{Thr}}$ and tRNA ${ }^{\text {Ser }}$ substrates with $U_{36}$ (Arimbasseri et al. 2016). Because we observed that $i^{6} \mathrm{~A}$ is important for both tRNA binding and $\mathrm{m}^{3} \mathrm{C}$ modification, this suggests that $\mathrm{tRNA}$ binding efficiency is at least partially responsible for the observed ordering of these two modifications. It remains to be determined how both $\mathrm{t}^{6} \mathrm{~A}$ and $\mathrm{i}^{6} \mathrm{~A}$ drive the same $\mathrm{m}^{3} \mathrm{C}$ modification reaction, and in particular if $\mathrm{t}^{6} \mathrm{~A}_{37}$ stimulates $\mathrm{m}^{3} \mathrm{C}$ modification due to increased Trm140 tRNA binding. Our preliminary attempts to express ORF240 in an sua5 mutant strain have been unsuccessful.

The ordered modification circuitry described above for $\mathrm{m}^{3} \mathrm{C}$ modification of $\mathrm{tRNA}^{\mathrm{Ser}}$ and $\mathrm{tRNA}^{\mathrm{Thr}}$ is reminiscent of the conserved ordered modification circuitry found in 


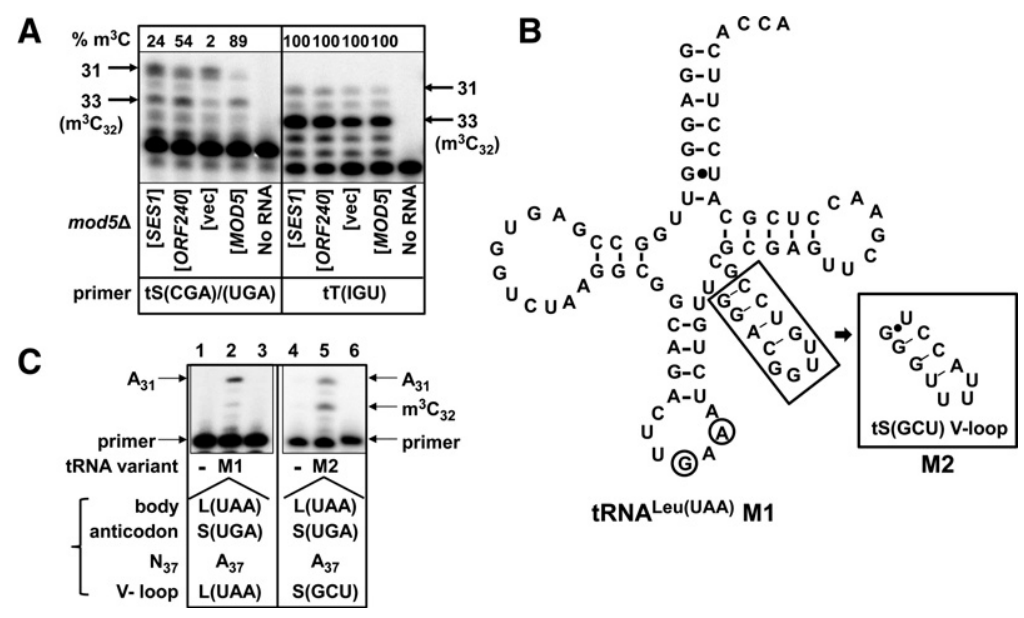

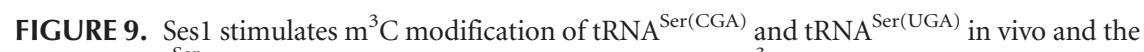
unique tRNA ${ }^{\text {Ser }} \mathrm{V}$-loop that Ses 1 recognizes is important for $\mathrm{m}^{3} \mathrm{C}$ modification. $(A)$ Ses1 stimulates $\mathrm{m}^{3} \mathrm{C}$ formation in vivo. Bulk RNA from mod5 $\Delta$ cells expressing SES1, ORF240, vector, or MOD5 as indicated was analyzed for $\mathrm{m}^{3} \mathrm{C}$ of $\mathrm{tRNA}^{\mathrm{Ser}(\mathrm{CGA}) /(\mathrm{UGA})}$ or tRNA ${ }^{\mathrm{Thr}(\mathrm{IGU})}$ by primer extension in the presence of ddTTP, as described in Materials and Methods. (B) Schematic of tRNA $^{\text {Leu(UAA) }} \mathrm{M} 1$ and M2 variants. The secondary structure of tRNA ${ }^{\text {Leu(UAA) }}$ M1 is shown, with anticodon loop mutations as indicated (circled). Nucleotides in the V-loop that were changed to the V-loop of tRNA ${ }^{\mathrm{Ser}(\mathrm{GCU})}$ to make the tRNA ${ }^{\mathrm{Leu}(\mathrm{UAA})} \mathrm{M} 2$ variant are boxed. $(C)$ The variable loop of $\mathrm{tRNA}{ }^{\mathrm{Ser}(\mathrm{GCU})}$ is sufficient to confer $\mathrm{m}^{3} \mathrm{C}$ modification in vivo of tRNA ${ }^{\text {Leu }}$ ${ }^{(\mathrm{UAA})}$ with $\mathrm{G}_{35}$ and $\mathrm{A}_{37}$ mutations. Variants described in $B$ were integrated into a trm $732 \Delta$ strain, to eliminate the possibility of $2^{\prime}-O$-methylation at $\mathrm{C}_{32}$ (Guy et al. 2012), and bulk RNA from strains containing either variants $\mathrm{M} 1$ or $\mathrm{M} 2$ was analyzed for $\mathrm{m}^{3} \mathrm{C}$ by primer extension, using ddTTP and primers extending from residue e 8 to 36 of M1 and from residue 47 to 36 of M2.

the anticodon loop of tRNA ${ }^{\text {Phe }}$. We previously showed that complete modification of the anticodon loop of $S$. cerevisiae tRNA ${ }^{\text {Phe }}$ required 2'-O-methylation of $\mathrm{C}_{32}$ and $\mathrm{G}_{34}$ to drive efficient formation of wybutosine at $\mathrm{m}^{1} \mathrm{G}_{37}$ (Guy et al. 2012), and that this circuitry for tRNA ${ }^{\text {Phe }}$ anticodon loop modification was conserved in S. pombe and human lymphoblastoid cell lines (Guy and Phizicky 2015; Guy et al. 2015). The similar conservation of modification order for $i^{6} \mathrm{~A} / \mathrm{t}^{6} \mathrm{~A}$ and $\mathrm{m}^{3} \mathrm{C}$ in the anticodon loops of tRNA ${ }^{\mathrm{Thr}}$ and $\mathrm{tRNA}{ }^{\mathrm{Ser}}$ species in S. cerevisiae and S. pombe suggests that this ordered modification circuitry will be preserved in other eukaryotes, perhaps by conserved mechanisms, and suggests the existence of other circuits for anticodon loop modifications.

The stimulation by Ses 1 of $\operatorname{Trm} 140 \mathrm{~m}^{3} \mathrm{C}$ modification activity that we observe in vitro and in vivo could occur in two ways. One possibility is that $\operatorname{Trm} 140$, Ses1, and tRNA form three binary interactions, which might stabilize weak enzyme-substrate binding. We have shown that Ses1-myc copurified with Trm140-cMORF, although it remains to be determined whether the interaction is tRNA mediated. Alternatively, it is possible that binding of tRNA ${ }^{\text {Ser }}$ to Ses 1 rearranges the local conformation of the anticodon loop to facilitate Trm140 recognition of $\mathrm{C}_{32}$, although the cocrystal structures of both Thermus thermophilus SerRS-tRNA ${ }^{\text {Ser }}$ and human SerRS-tRNA ${ }^{\text {Sec }}$ lack any direct interaction between the synthetases and the anticodon loop (Biou et al. 1994; Wang et al. 2015). It is known that S. cerevisiae Ses1 recognizes the V-loop of tRNA ${ }^{\text {Ser }}$ for its synthetase activity
(Himeno et al. 1997), providing a probable explanation for the V-loop dependence of $\mathrm{m}^{3} \mathrm{C}$ modification, but not casting light on its mechanism of $\mathrm{m}^{3} \mathrm{C}$ stimulation.

The two modes of tRNA substrate recognition for S. cerevisiae $\operatorname{Trm} 140$ seems likely to be found widely in the Saccharomycotina and Pezizomycotina subdivisions of the phylum Ascomycota, and to a more limited extent in Basidiomycota, based on the occurrence of a single highly similar TRM140 homo$\log$ in a large fraction of these organisms that we examined (Candida albicans, Candida tropicalis, Yarrowia lipolytica, Saccharomyces castellii, Debaryomyces hansenii, Candida glabrata, Saccharomyces mikatae, Saccharomyces paradoxus, Saccharomyces bayanus, Kluyveromyces lactis, Ashbya gossypii, Saccharomyces kluyveri, Kluyveromyces waltii, Aspergillus nidulans, Aspergillus oryzae, Neurospora crassa, Coccidioides posadasii, Coccidioides immitis, Coprinopsis cinerea, Phanerochaete chrysosporium, Uncinocarpus reesii. Chaetomium globosum, Fusarium verticillioides, Botrytis cinerea). However, split substrate recognition by $\operatorname{Trm} 140$ and related proteins is also likely widely found since $S$. pombe was recently shown to have separate trm140+ and trm141+ (METTL6) homologs dedicated to tRNA ${ }^{\text {Thr }}$ and to tRNA ${ }^{\text {Ser }}$ substrates, respectively, and multiple homologs appear to be the rule rather than the exception in metazoans, plants, and other groups of fungi (Arimbasseri et al. 2016). Thus, a large number of eukaryotes, including vertebrates, have two or three TRM140 family members, drawn from the phylogenetic clades of TRM140, METTL6, METTL2, and METTL8 homologs, which might be used for modification of specific tRNA species with $\mathrm{m}^{3} \mathrm{C}_{32}$ or with $\mathrm{m}^{3} \mathrm{C}$ in the $\mathrm{V}$-loop (Arimbasseri et al. 2016). In view of our findings, we speculate that $\mathrm{RNA}^{\mathrm{Ser}} \mathrm{m}^{3} \mathrm{C}$ modification activity in other organisms might also be stimulated by SerRS. In support of this, we note that the human SerRS has the same Vloop recognition element as yeast Ses1 (Achsel and Gross 1993). Alternatively, it is possible that the different homologs have evolved separate tRNA recognition elements in S. pombe and other organisms. The recent finding that the METTL6 homolog TbMTase37 of T. brucei is important for ribosome stability and cytokinesis emphasizes the importance of this family of proteins, although the proximate cause is not yet known (Fleming et al. 2016).

The Ses1 requirement for efficient $\operatorname{Trm} 140 \mathrm{~m}^{3} \mathrm{C}$ modification of tRNA ${ }^{\text {Ser }}$ species adds to a small subset of the two-subunit modification enzymes (Guy and Phizicky 2014) in which one interacting partner seemingly directs the enzyme to 
different residues or substrates, including $\operatorname{Trm} 7 / \operatorname{Trm} 732$ for $\mathrm{Nm}_{32}$ formation, Trm7/Trm734 for $\mathrm{Nm}_{34}$ formation (Guy et al. 2012; Guy and Phizicky 2015), and Kre33/Tan1 for $\mathrm{ac}^{4} \mathrm{C}_{12}$ formation (Johansson and Bystrom 2004; Sharma et al. 2015). The finding of Ses 1 as an interacting partner for $\operatorname{Trm} 140 \mathrm{~m}^{3} \mathrm{C}$ modification is also another example of the remarkable range of different noncanonical functions of tRNA synthetases (Wakasugi and Schimmel 1999; Guo et al. 2010; Smirnova et al. 2012; Yao and Fox 2013), at least some of which exert these roles through RNA interactions (Herbert et al. 1988; Sampath et al. 2004; Sarkar et al. 2012). It remains to be determined precisely how Ses 1 recognizes Trm140 to stimulate $\mathrm{m}^{3} \mathrm{C}$ modification activity of $\mathrm{tRNA}{ }^{\mathrm{Ser}}$, and the connection between tRNA ${ }^{\text {Ser }}$ charging and modification.

\section{MATERIALS AND METHODS}

\section{Yeast strains}

Strains (listed in Table 2) used for genetic tests and/or analysis of tRNA were derivatives of strain BY4741 or BY4742, strains used for immunoblotting analysis were derivatives of BCY123, and strains used for pull-down experiments and protein purification were derivatives of YLH126.

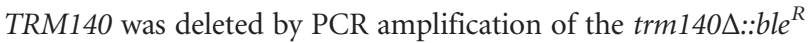
cassette from ySD179 using primers containing sequences $5^{\prime}$ and $3^{\prime}$ of TRM140 (TRM140 - 409 and TRM140 + 307), followed by transformation, selection on YPD media containing $8 \mathrm{mg} / \mathrm{L}$ Bleocin and verification by PCR using appropriate primers. MOD5 was deleted in a similar fashion.

The $t T(C G U) \triangle[C E N$ URA3 $t T(C G U)]$ strain was constructed by transformation of BY4741 with the [CEN URA3 tT(CGU)] plasmid containing the $t T(C G U)$ gene with its own flanking sequence, followed by PCR amplification of the $b l e^{R}$ marker and linear transformation to delete the $t T(C G U)$ gene.

Strains with the chromosomal cMORF tag $\left(\mathrm{His}_{6}-\mathrm{HA}-3 \mathrm{C}\right.$ site-ZZ domain of protein A) were generated by PCR amplification of a gene-specific product from a cMORF::URA3 cassette of pAVA0258, followed by linear transformation and selection (Gelperin et al. 2005; Guy et al. 2012). C-terminal myc-tagged strains were generated in a similar fashion from the pYM46 1myc7His: :Kan ${ }^{R}$ cassette (Janke et al. 2004).

\section{Plasmids}

Plasmids used in this study are listed in Table 3. Plasmids expressing tRNAs were constructed by ligation-independent cloning (LIC) of a tRNA with its own flanking sequence into the [2 $\mu$ LEU2] LIC vector pAVA577. LIC was also used to build the [CEN URA3 MOD5] plasmid. Integration vectors for tRNA variants were made by insertion of a BglII, Xhol fragment encoding the tRNA variant into plasmid pAB230-1, as previously described (Guy et al. 2014). ORF240 was cloned by LIC into a $[2 \mu$ URA3 $\left.\mathrm{P}_{G A L 1,10}\right]$ expression vector, in which ORF240 is expressed under $\mathrm{P}_{\text {GALI }}$ control with a C-terminal PT tag (as ORF240-3C site-HA epitope-His6-ZZ domain of protein A) essentially as previously described (Quartley et al. 2009).

\section{Expression and affinity purification of Ses1-MORF from yeast}

To purify Ses1 from yeast without interacting Trm140, strain YLH974-1 (trm140D) was transformed with a $\left[2 \mu\right.$ URA3 $\mathrm{P}_{G A L^{-}}$ SES1-MORF] plasmid encoding a SES1-MORF fusion protein (Ses1-His ${ }_{6}-\mathrm{HA}-3 \mathrm{C}$ site-ZZ domain of protein A), and the resulting strain was grown in selective media containing raffinose and induced for $6 \mathrm{~h}$ by addition of one-half volume of $3 \times$ YP media containing $6 \%$ galactose and $6 \%$ raffinose. Then Ses1-MORF was affinity purified using IgG Sepharose chromatography, followed by Ses1 elution with GST-3C protease, removal of the protease with glutathione Sepharose resin, and dialysis into buffer containing 50\% glycerol, $20 \mathrm{mM}$ Tris-Cl pH 7.5, $150 \mathrm{mM} \mathrm{NaCl}, 1 \mathrm{mM}$ $\mathrm{MgCl}_{2}$, and $1 \mathrm{mM} \mathrm{DTT}$, as previously described (Quartley et al. 2009).

TABLE 2. Strains used in this study

\begin{tabular}{|c|c|c|}
\hline Strain & Genotype & Source \\
\hline BY4741 & 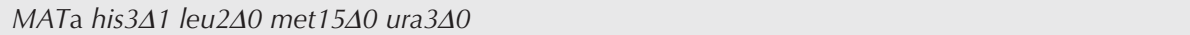 & Open Biosystems \\
\hline BY4742 & 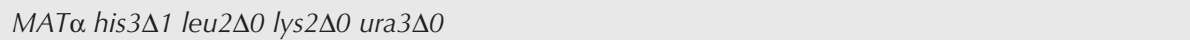 & Open Biosystems \\
\hline BCY123 & 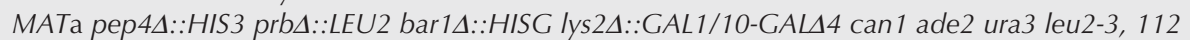 & Macbeth et al. (2005) \\
\hline YLH562-1 & BY4741 tT(CGU)A::ble ${ }^{R}[C E N$ URA tT(CGU)K] & This study \\
\hline T14 & сус1-1019 сус7-67 ura3-52 leu2-3, 112 суh2 & Na et al. (1992) \\
\hline YJN64 & сус 1-1019 сус7-67 ura3-52 leu2-3, 112 cyh2, sua5::LEU2 & Na et al. (1992) \\
\hline YLH126 & 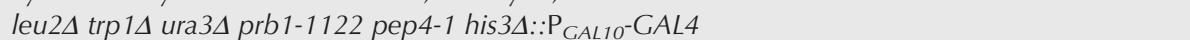 & Erin O'Shea \\
\hline ySD844 & BY4741 mod54::kan ${ }^{R}$ & This study \\
\hline ySD356 & BCY123 TRM140-CMORF-URA3 & This study \\
\hline YLH1302-1 & BCY123 SES1-1Myc-7His::kan ${ }^{R}$ & This study \\
\hline YLH1305-1 & BCY123 VAS1-1Myc-7His::kan ${ }^{R}$ & This study \\
\hline YLH1307-1 & BCY123 TRM140-cMORF::URA3 SES1-1Myc-7His::kan ${ }^{R}$ & This study \\
\hline YLH1310-1 & BCY123 TRM140-cMORF::URA3 VAS1-1Myc-7His::kan ${ }^{R}$ & This study \\
\hline yMG814-1 & BY4741 trm732A::ble ${ }^{R}$ & Guy et al. (2012) \\
\hline ySD179 & BY4742 trm $140:: b / e^{R}$ & D'Silva et al. (2011) \\
\hline YLH974-1 & YLH126 trm 140::ble ${ }^{R}$ & This study \\
\hline
\end{tabular}


TABLE 3. Plasmids used in this study

\begin{tabular}{|c|c|c|c|}
\hline Plasmid & Parent & Description & Source \\
\hline BG2663 & & $2 \mu \cup R A 3 \mathrm{P}_{\mathrm{GAL}}$ & Quartley et al. (2009) \\
\hline pSD142 & BG2663 & $2 \mu U R A 3 P_{G A L}-T R M 140-P T$ & D'Silva et al. (2011) \\
\hline pSD252 & BG2663 & $2 \mu U R A 3 P_{G A L}-O R F 240-P T$ & This study \\
\hline pAB230-1 & pJW132 & ade2::5'tH(GUG)G2::Fluc & Guy et al. (2014) \\
\hline pELH248-1 & pAB230-1 & ade2::5'tH(GUG)G2::tT(CGU) & This study \\
\hline pELH249-1 & pAB230-1 & ade2::5'tH(GUG)G2::tT(CGU) C28G-G42C U50A-A64U & This study \\
\hline pELH307-1 & pAB230-1 & ade2::5'tH(GUG)G2::tT(CGU) C28G-G42C U50A-A64U C32U & This study \\
\hline pELH308-1 & pAB230-1 & ade2::5'tH(GUG)G2::tT(CGU) C28G-G42C U50A-A64U C34A & This study \\
\hline pELH309-4 & pAB230-1 & ade2::5'tH(GUG)G2::tT(CGU) C28G-G42C U50A-A64U C34U & This study \\
\hline pELH310-4 & pAB230-1 & ade2::5'tH(GUG)G2::tT(CGU) C28G-G42C U50A-A64U C34G & This study \\
\hline pELH311-1 & pAB230-1 & ade2::5'tH(GUG)G2::tT(CGU) C28G-G42C U50A-A64U G35A & This study \\
\hline pELH312-2 & pAB230-1 & ade2::5'tH(GUG)G2::tT(CGU) C28G-G42C U50A-A64U G35U & This study \\
\hline pELH313-4 & pAB230-1 & ade2::5'tH(GUG)G2::tT(CGU) C28G-G42C U50A-A64U G35C & This study \\
\hline pELH314-2 & pAB230-1 & ade2::5'tH(GUG) G2::tT(CGU) C28G-G42C U50A-A64U U36A & This study \\
\hline pELH315-2 & pAB230-1 & ade2::5'tH(GUG)G2::tT(CGU) C28G-G42C U50A-A64U U36C & This study \\
\hline pELH316-5 & pAB230-1 & ade2::5'tH(GUG)G2::tT(CGU) C28G-G42C U50A-A64U U36G & This study \\
\hline pELH317-1 & pAB230-1 & ade2::5'tH(GUG)G2::tT(CGU) C28G-G42C U50A-A64U A38U & This study \\
\hline pELH318-1 & pAB230-1 & ade2::5'tH(GUG)G2::tT(CGU) C28G-G42C U50A-A64U A38C & This study \\
\hline pELH328-2 & pAB230-1 & ade2::5'tH(GUG)G2::tF(GAA) A29U-U41A U50A-A64U & This study \\
\hline pELH329-2 & pAB230-1 & ade2::5'tH(GUG)G2::tF(GAA) A29U-U41A U50A-A64U CGUA[34-37] & This study \\
\hline pJE832A & & $\mathrm{His}_{6}-\mathrm{GLN} 4-M O R F$ & Grant et al. (2012) \\
\hline pYM46 & & 1 Myc-7His::kan ${ }^{R}$ & Janke et al. (2004) \\
\hline pAVA577 & & $2 \mu L E U 2$ LIC vector & Alexandrov et al. (2006) \\
\hline pJW038 & pAVA577 & $2 \mu L E U 2$ tS $(C G A)$ & Whipple et al. (2011) \\
\hline pEKD9094 & pAVA577 & $2 \mu L E U 2 t T(C G U)$ & Han et al. (2015) \\
\hline pJW043 & pAVA577 & $2 \mu L E U 2 t S(U G A)$ & Han et al. (2015) \\
\hline pELH106-1 & pAVA577 & $2 \mu L E U 2 t T(U G U)$ & Han et al. (2015) \\
\hline pELH419-1 & pAVA577 & $2 \mu L E U 2 t S(G C U) F$ & This study \\
\hline pAVA579 & & CEN URA3 LIC vector & Quartley et al. (2009) \\
\hline pELN010 & pAVA579 & CEN URA3 MOD5 & This study \\
\hline pAVA0258 & & $\mathrm{His}_{6}-\mathrm{HA}-3 \mathrm{C}$-protein $\mathrm{A}:: U R A 3$ cassette & Gelperin et al. (2005) \\
\hline pJE1256A & & $\mathrm{P}_{\mathrm{GAL}}-\mathrm{SES} 1-\mathrm{MORF}$ & Gelperin et al. (2005) \\
\hline pAVA421 & & pT7-His ${ }_{6}-3 \mathrm{C}$ site-ORF LIC vector & Quartley et al. (2009) \\
\hline pSD248 & pAVA421 & $\mathrm{His}_{6}-3 \mathrm{C}-\mathrm{ATG}-\mathrm{ORF} 240$ & D'Silva et al. (2011) \\
\hline
\end{tabular}

\section{Growth and affinity purification of His6-ORF240 from $E$. coli}

The E. coli expression plasmid pSD248, which expresses the entire C-terminal domain of TRM140 (residues 277-628, called ORF240) as a His6-3C-ORF240 fusion, was transformed into pLys(S)BL21 (DE3) cells. Transformants were grown, induced, and harvested, and then tagged protein was purified using immobilized metal ion affinity chromatography (IMAC), followed by imidazole elution, cleavage of the affinity tag with protease $3 \mathrm{C}$, removal of contaminants by passage through the same IMAC resin, and dialysis into buffer containing 50\% glycerol, $20 \mathrm{mM}$ Tris-Cl, $\mathrm{pH} 7.5,200 \mathrm{mM} \mathrm{NaCl}$, and $1 \mathrm{mM}$ DTT, essentially as previously described (D'Silva et al. 2011).

\section{Extraction of bulk RNA from yeast and purification of tRNA}

Strains were grown to an $\mathrm{OD}_{600} 1-2$, and bulk RNA was extracted from $\sim 300$ OD pellets (for tRNA purification) or from $\sim 3$ OD pellets (for primer extension analysis) using hot phenol. tRNA was purified from $\sim 1.25 \mathrm{mg}$ bulk RNA using 5'-biotinylated oligonucleotides (Integrated DNA Technologies), as previously described (Jackman et al. 2003).

\section{Primer extension assays}

Primers were $5^{\prime}$ end labeled and purified as previously described (D'Silva et al. 2011). In a $5 \mu \mathrm{L}$ annealing reaction, $0.25-1 \mathrm{pmol}$ of labeled primers were annealed to $0.4-3 \mu \mathrm{g}$ of bulk RNA or $\sim 3 \mathrm{ng}$ of purified tRNA by incubation for $3 \mathrm{~min}$ at $95^{\circ} \mathrm{C}$ followed by slow cooling and incubation for $30 \mathrm{~min}$ at $50^{\circ} \mathrm{C}-55^{\circ} \mathrm{C}$. The annealing product was then extended using $64 \mathrm{U}$ Superscript III (Invitrogen) in a $10 \mu \mathrm{L}$ reaction containing $1 \times$ First Strand buffer, $1 \mathrm{mM}$ of each dNTP, and $10 \mathrm{mM} \mathrm{MgCl}_{2}$ at $50^{\circ} \mathrm{C}-55^{\circ} \mathrm{C}$ for 1 h. For reactions containing ddTTP, dTTP was replaced by $2 \mathrm{mM}$ ddTTP, and other dNTPs were reduced to $0.5 \mathrm{mM}$. Reactions were stopped by addition of $2 \times$ RNA loading dye containing $98 \%$ formamide, $10 \mathrm{mM}$ EDTA, $1 \mathrm{mg} / \mathrm{mL}$ bromophenol blue, and 1 $\mathrm{mg} / \mathrm{mL}$ xylene cyanol, resolved on a $7 \mathrm{M}$ urea-15\% polyacrylamide gel, and the dried gel was imaged on a Typhoon phosphorimager and quantified as previously described (Jackman et al. 2003).

\section{ORF240 and Trm140 pull-down assays of tRNA binding}

Strains expressing $\mathrm{P}_{G A L^{-}}$ORF240-PT or $\mathrm{P}_{G A L^{-}}$TRM140-PT plasmid were grown in selective media containing raffinose to $\mathrm{OD}_{600}$ $\sim 0.75$ and induced for $6 \mathrm{~h}$ with one-half volume $3 \times \mathrm{YP}$ media 
containing $6 \%$ galactose and $6 \%$ raffinose. Then tagged proteins were affinity purified from 320-360 OD pellets using IgG Sepharose, followed by one or two washes with $1 \mathrm{~mL}$ buffer and 3 min of mixing, and then overnight incubation with GST-3C protease to release bound protein and copurifying tRNAs. Then RNA was purified from each fraction, resolved by PAGE, and tRNAs were analyzed by hybridization, as previously described (Alexandrov et al. 2006).

\section{Mass spectrometry}

For mass spectrometry analysis of ORF240 binding proteins, ORF240-PT purification was done as for a pull-down assay, proteins were analyzed by SDS-PAGE, and copurifying polypeptides were analyzed by the Mass Spectrometry Resource Center of the University of Rochester Medical Center.

\section{Immunoblotting analysis}

Yeast strains with C-terminal chromosomal tags (cMORF or myc) were grown in YPD to $\mathrm{OD}_{600} 1-2.5$ and crude extracts were made from 500-600 OD-mL pellets, followed by IgG Sepharose affinity purification and elution of bound protein with GST-3C protease. Then samples were subject to SDS-PAGE, transferred to nitrocellulose membrane (Bio-Rad), and probed with appropriate antibodies: mouse monoclonal anti-[c-myc] (Roche), followed by goat anti-mouse IgG-HRP (Bio-Rad); or rat anti-HA (Roche), followed by goat anti-rat IgG-HRP (Bio-Rad). Strains containing a $\mathrm{P}_{G A L}-O R F 240-P T$ plasmid were grown as described in pull-down experiment.

\section{Assay of $\mathbf{m}^{3} \mathrm{C}$ methyltransferase activity in vitro}

Reaction mixtures $(20 \mu \mathrm{L})$ contained $60-67.5 \mathrm{mM} \mathrm{NaCl}, 50 \mathrm{mM}$ Hepes, $\mathrm{pH} 7.5,3 \mathrm{mM} \mathrm{MgCl}, 55-60 \mu \mathrm{g} / \mathrm{mL}$ BSA, $50 \mu \mathrm{M}$ EDTA, 2.5-3.5 mM Tris-Cl pH 7.5, 2.5-5\% glycerol, $0.5 \mathrm{mM}$ SAM, $50 \mu \mathrm{g} / \mathrm{mL}$ Poly(A), $10 \mathrm{ng}$ of purified and refolded tRNA

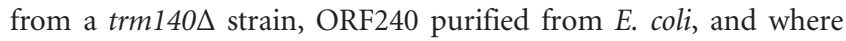
indicated, Ses1 purified from a trm $140 \Delta$ strain or compensating buffer. Reactions were incubated at $30^{\circ} \mathrm{C}$ for $1 \mathrm{~h}$, stopped by phenol extraction, and then tRNA was precipitated with ethanol, resuspended in water, and subjected to primer extension analysis to analyze $\mathrm{m}^{3} \mathrm{C}_{32}$.

\section{ACKNOWLEDGMENTS}

We thank E. O'Shea and M. Hampsey for strains, S. Ghaemmaghami and K. Welle of the Mass Spectrometry Resource Center of the University of Rochester Medical Center, and E. Grayhack for valuable discussions and comments during the course of this work. This research was supported by National Institutes of Health grant GM052347 to E.M.P.

Received October 20, 2016; accepted December 12, 2016.

\section{REFERENCES}

Achsel T, Gross HJ. 1993. Identity determinants of human tRNA ${ }^{\text {Ser }}$ : sequence elements necessary for serylation and maturation of a tRNA with a long extra arm. EMBO J 12: 3333-3338.

Agris PF, Vendeix FA, Graham WD. 2007. tRNA's wobble decoding of the genome: 40 years of modification. J Mol Biol 366: 1-13.

Alexandrov A, Chernyakov I, Gu W, Hiley SL, Hughes TR, Grayhack EJ, Phizicky EM. 2006. Rapid tRNA decay can result from lack of nonessential modifications. Mol Cell 21: 87-96.

Arimbasseri AG, Iben J, Wei FY, Rijal K, Tomizawa K, Hafner M, Maraia RJ. 2016. Evolving specificity of tRNA 3-methyl-cytidine$32\left(\mathrm{~m}^{3} \mathrm{C} 32\right)$ modification: a subset of tRNAs ${ }^{\text {Ser }}$ requires $N^{6}$-isopentenylation of A37. RNA 22: 1400-1410.

Auffinger P, Westhof E. 1999. Singly and bifurcated hydrogen-bonded base-pairs in tRNA anticodon hairpins and ribozymes. J Mol Biol 292: 467-483.

Biou V, Yaremchuk A, Tukalo M, Cusack S. 1994. The 2.9 A crystal structure of $T$. thermophilus seryl-tRNA synthetase complexed with tRNA ${ }^{\text {Ser }}$. Science 263: 1404-1410.

Bjork GR, Jacobsson K, Nilsson K, Johansson MJ, Bystrom AS, Persson OP. 2001. A primordial tRNA modification required for the evolution of life? EMBO J 20: 231-239.

Bjork GR, Huang B, Persson OP, Bystrom AS. 2007. A conserved modified wobble nucleoside $\left(\mathrm{mcm}^{5} \mathrm{~s}^{2} \mathrm{U}\right)$ in lysyl-tRNA is required for viability in yeast. RNA 13: 1245-1255.

Chen C, Huang B, Eliasson M, Ryden P, Bystrom AS. 2011. Elongator complex influences telomeric gene silencing and DNA damage response by its role in wobble uridine tRNA modification. PLoS Genet 7: e1002258.

Dihanich ME, Najarian D, Clark R, Gillman EC, Martin NC, Hopper AK. 1987. Isolation and characterization of MOD5, a gene required for isopentenylation of cytoplasmic and mitochondrial tRNAs of Saccharomyces cerevisiae. Mol Cell Biol 7: 177-184.

D'Silva S, Haider SJ, Phizicky EM. 2011. A domain of the actin binding protein Abp140 is the yeast methyltransferase responsible for 3methylcytidine modification in the tRNA anti-codon loop. RNA 17: $1100-1110$.

El Yacoubi B, Lyons B, Cruz Y, Reddy R, Nordin B, Agnelli F, Williamson JR, Schimmel P, Swairjo MA, de Crecy-Lagard V. 2009. The universal YrdC/Sua5 family is required for the formation of threonylcarbamoyladenosine in tRNA. Nucleic Acids Res 37: 2894-2909.

El Yacoubi B, Hatin I, Deutsch C, Kahveci T, Rousset JP, Iwata-Reuyl D, Murzin AG, de Crécy-Lagard V. 2011. A role for the universal Kae1/ Qri7/YgjD (COG0533) family in tRNA modification. EMBO J 30: 882-893.

Esberg A, Huang B, Johansson MJ, Bystrom AS. 2006. Elevated levels of two tRNA species bypass the requirement for elongator complex in transcription and exocytosis. Mol Cell 24: 139-148.

Fleming IM, Paris Z, Gaston KW, Balakrishnan R, Fredrick K, Rubio MA, Alfonzo JD. 2016. A tRNA methyltransferase paralog is important for ribosome stability and cell division in Trypanosoma brucei. Sci Rep 6: 21438.

Gelperin DM, White MA, Wilkinson ML, Kon Y, Kung LA, Wise KJ, Lopez-Hoyo N, Jiang L, Piccirillo S, Yu H, et al. 2005. Biochemical and genetic analysis of the yeast proteome with a movable ORF collection. Genes Dev 19: 2816-2826.

Gerber AP, Keller W. 1999. An adenosine deaminase that generates inosine at the wobble position of tRNAs. Science 286: 1146-1149.

Grant TD, Snell EH, Luft JR, Quartley E, Corretore S, Wolfley JR, Snell ME, Hadd A, Perona JJ, Phizicky EM, et al. 2012. Structural conservation of an ancient tRNA sensor in eukaryotic glutaminyltRNA synthetase. Nucleic Acids Res 40: 3723-3731.

Guo M, Yang XL, Schimmel P. 2010. New functions of aminoacyl-tRNA synthetases beyond translation. Nat Rev Mol Cell Biol 11: 668-674.

Guy MP, Phizicky EM. 2014. Two-subunit enzymes involved in eukaryotic post-transcriptional tRNA modification. RNA Biol 11: $1608-1618$. 
Guy MP, Phizicky EM. 2015. Conservation of an intricate circuit for crucial modifications of the tRNA ${ }^{\text {Phe }}$ anticodon loop in eukaryotes RNA 21: 61-74.

Guy MP, Podyma BM, Preston MA, Shaheen HH, Krivos KL, Limbach PA, Hopper AK, Phizicky EM. 2012. Yeast Trm7 interacts with distinct proteins for critical modifications of the tRNA ${ }^{\text {Phe }}$ anticodon loop. RNA 18: 1921-1933.

Guy MP, Young DL, Payea MJ, Zhang X, Kon Y, Dean KM, Grayhack EJ, Mathews DH, Fields S, Phizicky EM. 2014. Identification of the determinants of tRNA function and susceptibility to rapid tRNA decay by high-throughput in vivo analysis. Genes Dev 28: 1721-1732.

Guy MP, Shaw M, Weiner CL, Hobson L, Stark Z, Rose K, Kalscheuer VM, Gecz J, Phizicky EM. 2015. Defects in tRNA anticodon loop 2'-O-methylation are implicated in nonsyndromic Xlinked intellectual disability due to mutations in FTSJ1. Hum Mutat 36: 1176-1187.

Hall TM. 2005. Multiple modes of RNA recognition by zinc finger proteins. Curr Opin Struct Biol 15: 367-373.

Han L, Kon Y, Phizicky EM. 2015. Functional importance of $\Psi 38$ and $\Psi 39$ in distinct tRNAs, amplified for tRNA ${ }^{\mathrm{Gln}(\mathrm{UUG})}$ by unexpected temperature sensitivity of the $s^{2} \mathrm{U}$ modification in yeast. RNA 21 188-201.

Helm M, Giege R, Florentz C. 1999. A Watson-Crick base-pair-disrupting methyl group ( $\left.\mathrm{m}^{1} \mathrm{~A} 9\right)$ is sufficient for cloverleaf folding of human mitochondrial tRNA ${ }^{\text {Lys }}$. Biochemistry 38: 13338-13346.

Herbert CJ, Labouesse M, Dujardin G, Slonimski PP. 1988. The NAM2 proteins from S. cerevisiae and S. douglasii are mitochondrial leucyltRNA synthetases, and are involved in mRNA splicing. EMBO J 7: 473-483.

Himeno H, Yoshida S, Soma A, Nishikawa K. 1997. Only one nucleotide insertion to the long variable arm confers an efficient serine acceptor activity upon Saccharomyces cerevisiae tRNA ${ }^{\text {Leu }}$ in vitro. J Mol Biol 268: 704-711.

Hur S, Stroud RM. 2007. How U38, 39, and 40 of many tRNAs become the targets for pseudouridylation by TruA. Mol Cell 26: 189-203.

Jackman JE, Phizicky EM. 2006. tRNA ${ }^{\text {His }}$ guanylyltransferase adds G-1 to the $5^{\prime}$ end of tRNA ${ }^{\text {His }}$ by recognition of the anticodon, one of several features unexpectedly shared with tRNA synthetases. RNA 12: 1007-1014.

Jackman JE, Montange RK, Malik HS, Phizicky EM. 2003. Identification of the yeast gene encoding the tRNA $\mathrm{m}^{1} \mathrm{G}$ methyltransferase responsible for modification at position 9. RNA 9: 574-585.

Janke C, Magiera MM, Rathfelder N, Taxis C, Reber S, Maekawa H, Moreno-Borchart A, Doenges G, Schwob E, Schiebel E, et al. 2004. A versatile toolbox for PCR-based tagging of yeast genes: new fluorescent proteins, more markers and promoter substitution cassettes. Yeast 21: 947-962.

Johansson MJ, Bystrom AS. 2004. The Saccharomyces cerevisiae TAN1 gene is required for $N^{4}$-acetylcytidine formation in tRNA. RNA 10: $712-719$.

Johansson MJ, Esberg A, Huang B, Bjork GR, Bystrom AS. 2008. Eukaryotic wobble uridine modifications promote a functionally redundant decoding system. Mol Cell Biol 28: 3301-3312.

Juhling F, Morl M, Hartmann RK, Sprinzl M, Stadler PF, Putz J. 2009. tRNAdb 2009: compilation of tRNA sequences and tRNA genes. Nucleic Acids Res 37: D159-D162.

Kadaba S, Krueger A, Trice T, Krecic AM, Hinnebusch AG, Anderson J. 2004. Nuclear surveillance and degradation of hypomodified initiator tRNA ${ }^{\mathrm{Met}}$ in S. cerevisiae. Genes Dev 18: 1227-1240.

Ledoux S, Olejniczak M, Uhlenbeck OC. 2009. A sequence element that tunes Escherichia coli tRNA ${ }_{\text {GGC }}^{\mathrm{Ala}}$ to ensure accurate decoding. Nat Struct Mol Biol 16: 359-364.

Lu D, Searles MA, Klug A. 2003. Crystal structure of a zinc-finger-RNA complex reveals two modes of molecular recognition. Nature 426: 96-100.

Lustig F, Boren T, Claesson C, Simonsson C, Barciszewska M, Lagerkvist U. 1993. The nucleotide in position 32 of the tRNA anticodon loop determines ability of anticodon UCC to discriminate among glycine codons. Proc Natl Acad Sci 90: 3343-3347.
Macbeth MR, Schubert HL, Vandemark AP, Lingam AT, Hill CP, Bass BL. 2005. Inositol hexakisphosphate is bound in the ADAR2 core and required for RNA editing. Science 309: 1534-1539.

Machnicka MA, Milanowska K, Osman Oglou O, Purta E, Kurkowska M, Olchowik A, Januszewski W, Kalinowski S, DuninHorkawicz S, Rother KM, et al. 2013. MODOMICS: a database of RNA modification pathways-2013 update. Nucleic Acids Res 41: D262-D267.

Miyauchi K, Kimura S, Suzuki T. 2013. A cyclic form of $N^{6}$-threonylcarbamoyladenosine as a widely distributed tRNA hypermodification. Nat Chem Biol 9: 105-111.

Moitoso de Vargas L, Pargellis CA, Hasan NM, Bushman EW, Landy A. 1988. Autonomous DNA binding domains of $\lambda$ integrase recognize two different sequence families. Cell 54: 923-929.

Murphy FVt, Ramakrishnan V. 2004. Structure of a purine-purine wobble base pair in the decoding center of the ribosome. Nat Struct Mol Biol 11: 1251-1252.

Na JG, Pinto I, Hampsey M. 1992. Isolation and characterization of SUA5, a novel gene required for normal growth in Saccharomyces cerevisiae. Genetics 131: 791-801.

Nakamura A, Nemoto T, Heinemann IU, Yamashita K, Sonoda T, Komoda K, Tanaka I, Soll D, Yao M. 2013. Structural basis of reverse nucleotide polymerization. Proc Natl Acad Sci 110: 20970-20975.

Nolte RT, Conlin RM, Harrison SC, Brown RS. 1998. Differing roles for zinc fingers in DNA recognition: structure of a six-finger transcription factor IIIA complex. Proc Natl Acad Sci 95: 2938-2943.

Noma A, Yi S, Katoh T, Takai Y, Suzuki T, Suzuki T. 2011. Actin-binding protein $\mathrm{ABP} 140$ is a methyltransferase for 3-methylcytidine at position 32 of tRNAs in Saccharomyces cerevisiae. RNA 17: $1111-1119$.

Olejniczak M, Uhlenbeck OC. 2006. tRNA residues that have coevolved with their anticodon to ensure uniform and accurate codon recognition. Biochimie 88: 943-950.

Olejniczak M, Dale T, Fahlman RP, Uhlenbeck OC. 2005. Idiosyncratic tuning of tRNAs to achieve uniform ribosome binding. Nat Struct Mol Biol 12: 788-793.

Pintard L, Lecointe F, Bujnicki JM, Bonnerot C, Grosjean H, Lapeyre B. 2002. Trm7p catalyses the formation of two $2^{\prime}-O$-methylriboses in yeast tRNA anticodon loop. EMBO J 21: 1811-1820.

Quartley E, Alexandrov A, Mikucki M, Buckner FS, Hol WG, DeTitta GT, Phizicky EM, Grayhack EJ. 2009. Heterologous expression of L. major proteins in S. cerevisiae: a test of solubility, purity, and gene recoding. J Struct Funct Genomics 10: 233-247.

Sampath P, Mazumder B, Seshadri V, Gerber CA, Chavatte L, Kinter M, Ting SM, Dignam JD, Kim S, Driscoll DM, et al. 2004. Noncanonical function of glutamyl-prolyl-tRNA synthetase: gene-specific silencing of translation. Cell 119: 195-208.

Sarkar J, Poruri K, Boniecki MT, McTavish KK, Martinis SA. 2012. Yeast mitochondrial leucyl-tRNA synthetase CP1 domain has functionally diverged to accommodate RNA splicing at expense of hydrolytic editing. J Biol Chem 287: 14772-14781.

Sharma S, Langhendries JL, Watzinger P, Kotter P, Entian KD, Lafontaine DL. 2015. Yeast Kre33 and human NAT10 are conserved $18 \mathrm{~S}$ rRNA cytosine acetyltransferases that modify tRNAs assisted by the adaptor Tan1/THUMPD1. Nucleic Acids Res 43: 2242-2258.

Shimada N, Suzuki T, Watanabe K. 2001. Dual mode recognition of two isoacceptor tRNAs by mammalian mitochondrial seryl-tRNA synthetase. J Biol Chem 276: 46770-46778.

Smirnova EV, Lakunina VA, Tarassov I, Krasheninnikov IA, Kamenski PA. 2012. Noncanonical functions of aminoacyl-tRNA synthetases. Biochemistry (Mosc) 77: 15-25.

Swinehart WE, Jackman JE. 2015. Diversity in mechanism and function of tRNA methyltransferases. RNA Biol 12: 398-411.

Swinehart WE, Henderson JC, Jackman JE. 2013. Unexpected expansion of tRNA substrate recognition by the yeast $\mathrm{m}^{1} \mathrm{G} 9$ methyltransferase Trm10. RNA 19: 1137-1146. 
Urbonavicius J, Qian Q, Durand JM, Hagervall TG, Bjork GR. 2001. Improvement of reading frame maintenance is a common function for several tRNA modifications. EMBO J 20: 4863-4873.

Waas WF, Druzina Z, Hanan M, Schimmel P. 2007. Role of a tRNA base modification and its precursors in frameshifting in eukaryotes. J Biol Chem 282: 26026-26034.

Wakasugi K, Schimmel P. 1999. Two distinct cytokines released from a human aminoacyl-tRNA synthetase. Science 284: 147-151.

Wang C, Guo Y, Tian Q, Jia Q, Gao Y, Zhang Q, Zhou C, Xie W. 2015. SerRS-tRNA ${ }^{\text {Sec }}$ complex structures reveal mechanism of the first step in selenocysteine biosynthesis. Nucleic Acids Res 43: 10534-10545.
Weissenbach J, Kiraly I, Dirheimer G. 1977. Primary structure of tRNA Thr la and b from brewer's yeast. Biochimie 59: 381-391.

Weixlbaumer A, Murphy FVt, Dziergowska A, Malkiewicz A, Vendeix FA, Agris PF, Ramakrishnan V. 2007. Mechanism for expanding the decoding capacity of transfer RNAs by modification of uridines. Nat Struct Mol Biol 14: 498-502.

Whipple JM, Lane EA, Chernyakov I, D’Silva S, Phizicky EM. 2011. The yeast rapid tRNA decay pathway primarily monitors the structural integrity of the acceptor and T-stems of mature tRNA. Genes Dev 25: $1173-1184$.

Yao P, Fox PL. 2013. Aminoacyl-tRNA synthetases in medicine and disease. EMBO Mol Med 5: 332-343. 

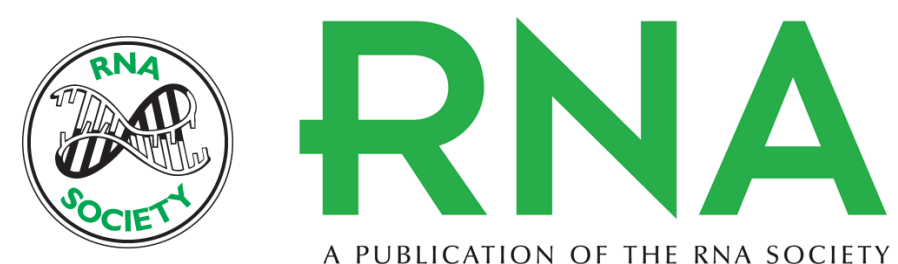

A PUBLICATION OF THE RNA SOCIETY

\section{S. cerevisiae Trm140 has two recognition modes for 3-methylcytidine modification of the anticodon loop of tRNA substrates}

Lu Han, Erin Marcus, Sonia D'Silva, et al.

RNA 2017 23: 406-419 originally published online December 21, 2016

Access the most recent version at doi:10.1261/rna.059667.116

References This article cites 68 articles, 32 of which can be accessed free at:

http://rnajournal.cshlp.org/content/23/3/406.full.html\#ref-list-1

Creative This article is distributed exclusively by the RNA Society for the first 12 months after the

Commons full-issue publication date (see http://rnajournal.cshlp.org/site/misc/terms.xhtml). After 12

License months, it is available under a Creative Commons License (Attribution-NonCommercial 4.0 International), as described at http://creativecommons.org/licenses/by-nc/4.0/.

Email Alerting Receive free email alerts when new articles cite this article - sign up in the box at the

Service top right corner of the article or click here.

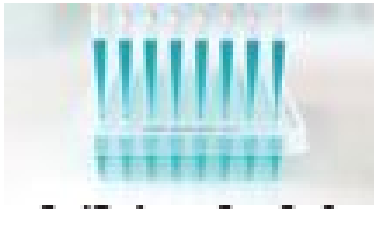

Providing Precise Solutions for your research.

To subscribe to $R N A$ go to:

http://rnajournal.cshlp.org/subscriptions

(C) 2017 Han et al.; Published by Cold Spring Harbor Laboratory Press for the RNA Society 